\title{
EL VIAJE Y LO MONSTRUOSO EN EL SIGLO XVIII POR UNA ÉTICA-ESTÉTICA DEL GRAND TOUR *
}

\author{
Nieves Soriano Nieto \\ Filósofa - IES Misteri d’Elx, Elche (Alicante)
}

\begin{abstract}
Resumen.- En este artículo se trata de analizar, desde la Historia de las Ideas Estéticas, cómo evolucionaron las mismas en la Europa de los viajeros que realizaron el Grand Tour a Italia. Tales viajeros realizaban el periplo buscando lo Clásico en la época de las Luces. Pero en ocasiones, en concreto en su recorrido por Sicilia, se encontraron con la Sombra de lo Monstruoso. ¿Cómo se vive en la Europa llustrada desde un punto de vista ético-estético tal encuentro?
\end{abstract}

Palabras clave.- Grand Tour; estética; ilustración; viaje; literatura; ideas; representación; Sicilia.

Abstract.- In this article we will analyze how aesthetics ideas evolved in Europe when travelling to Italy to make the Grand Tour. In the Enlightenment, travellers moved to Italy searching classicism. Nevertheless, in Sicily, they found also monstruosness as a part of the shade. How did the Enlighted Europe lived this meeting from an ethical and aesthetic point of view?

Keywords.- Grand Tour; Aesthetics; enlightenment; travel; literature; ideas; representation; Sicily.

\section{Introducción}

En 1486, Al-Ashraf Kait Bey, el Mameluco, sultán de Egipto, presentó a Lorenzo di Medici una jirafa que ofreció como regalo para establecer buenas relaciones diplomáticas con los florentinos ${ }^{1}$. Un animal procedente de un país lejano, podría decirse oriental, suponía para un lugar como Florencia un alarde de exotismo que relata una mirada hacia el mundo ávida de conocimiento. En cada época, el gusto hacia lo bizarro, extraño, desconocido, en suma, monstruoso, se desarrolla de una manera precipitada. Tener un pedazo de aquello que no podía todavía ser explicado, en el Renacimiento, implicaba dar un paso más hacia el conocimiento del mismo, o bien convertirse en hilandero de la oscuridad. El descubridor podía convertirse en una de las personas más avanzadas en tanto que sólo progresa aquel ser humano que es capaz de ir caminando hacia la apropiación del mundo a través de una mirada humana que

\footnotetext{
${ }^{1}$ RINGMAR, E. (2006).
} 
mide, entiende y geometriza. Spinoza, por ejemplo, en su Ética demostrada según el orden geométrico ${ }^{2}$, se sumergía en la incertidumbre del acto humano, a veces guiado por el ímpetu irracional. Ésta, si era pautada por la racionalidad y certidumbre en la demostración de la geometría, podría esclarecer cada decisión humana en su comportamiento, de tal manera que, pensaba Spinoza, si no se sale uno de la deducción, no existirá el Mal en la actuación. Se trataba, pues, de gobernar lo ingobernable, de comenzar a dar luz a la oscuridad. El monstruo, nacido de la sombra, al conocerlo, dibujarlo, verlo, puede llegar a entenderse, $y$, por tanto, puede comprenderse haciéndole abandonar su existencia monstruosa.

Así, para los Medici, cualquier animal exótico se convertía en un inicio hacia la apropiación de lo desconocido. No en vano tenían su propio zoológico compuesto de las especies más extrañas que iban llegando. Tampoco en vano, cuando se realizaba una gran recepción, como fue la que se hizo en honor al Papa Pío II en 1459, se realizaba un despliegue de todo el zoológico en una exhibición que atravesaba las calles de la ciudad de las ciencias y las letras renacentistas, dando a entender que eran los Medici los que, poseyendo lo extraño, podían partir y ser dueños del conocimiento.

Al-Ashraf Kait Bey, el Mameluco, sultán de Egipto, comprendiendo, bien sea intuitivamente, o realmente el trasfondo de la mirada en la historia florentina de la época, regaló a Lorenzo de Medici la jirafa para que completase su jardín de animales exóticos, porque así abriría buenas relaciones con Florencia, quien, estando también en armoniosas relaciones diplomáticas con los Turcos, que en aquella época estaban en guerra contra los venecianos, podrían ayudar a Egipto a calmar las tensiones que les habían surgido con ellos. A fin de cuentas podemos observar que es a través de la mirada como Al-Ashraf Kait Bey, el Mameluco, sultán de Egipto comprende que debe comenzar a construir una Historia para la época que camine a su favor.

A fin de cuentas, podemos observar cómo es a raíz de datos que tienen que ver con la mirada, y con la interpretación o conciencia de la misma como se escribe también la Historia de cada civilización. ¿Desde dónde podemos comenzar cuando tratamos de reflexionar sobre una época?

La Historia clásica ha tratado de buscar las raíces desde las que comenzar en las relaciones económicas entre los ciudadanos. Con ella, la mirada descriptiva del ser humano es atravesada por intereses materiales y de relaciones de poder $^{3}$. Es evidente que no se puede hablar de la historia sin tratar la economía. Sin embargo, es esclarecedor que se consideren también otras perspectivas, en tanto que los seres humanos son más que mero interés, o quizás interés más sofisticado. ¿Qué hay de la historia del pensamiento? ¿Y del devenir de los productos culturales? Estas mismas preguntas se las realizaron Peter Burke, Jean Starobinski o Richard Sennett ${ }^{4}$.

Es ése, pues, el punto de vista desde el que vamos a comenzar. Se considerará que toda muestra cultural de un individuo -como puede ser una obra de arte, un escrito literario, una fotografía, una puesta en escena, etc.- no es un hecho aislado dentro de las inquietudes de un sujeto, sino que es algo

\footnotetext{
${ }^{2}$ SPINOZA, B. (2007).

${ }^{3}$ MARX, K. (2003). Siguiendo esta línea, léanse cualquiera de los escritos de Eric Hobsbawm.

${ }^{4}$ BURKE, P. (2002 y (2005); STAROBINSKI, J. (1988); SENNETT, R. (1991 y 1997).
} 
sintomático de la sociedad y la forma de pensamiento a la que está arraigada la persona que ha realizado la obra. Así, nosotros, mirada actual hacia las épocas pasadas, tarea innata de historiador miope ante tanta lectura, trataremos de explicar lo que existió detrás en base a lo que fue manifiesto. Nos adentramos en el mundo de la monstruosidad.

\section{Lo monstruoso}

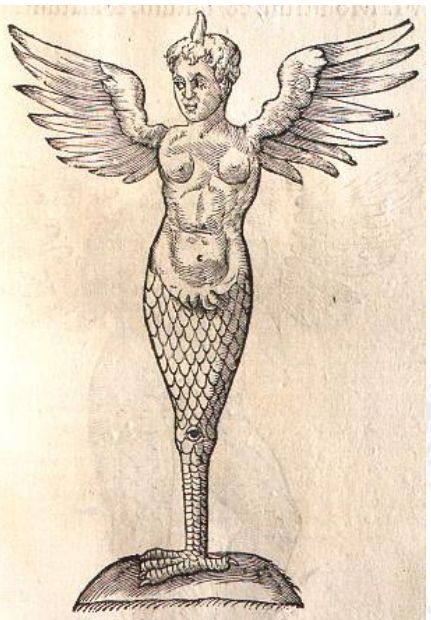

Ulysse Aldrovandi, Monstruo de Ravenna

Monstrorum historia (1658)

En Ravenna nació de una mujer un monstruo que viene aquí descrito; y tenía sobre la cabeza un cuerno recto que parecía una espada, y en vez de brazos tenía dos alas cual murciélago, y donde se encuentran los pechos tenía en el lado derecho tenía una flor, y en el izquierdo una cruz, y más abajo, en la cintura, dos serpientes, y donde se encuentra la naturaleza, la tenía de hembra y de macho; la de hembra estaba más arriba y la de macho más abajo; en la rodilla derecha tenía un ojo, y en el pie ausente tenía un águila. Lo vi yo dibujado, y para quien lo desee ver, en Florencia 5 .

El caso aquí expuesto por Luca Landucci, escogido puramente al azar y al hilo del pensamiento, es uno de los innumerables que ha producido la historia de la humanidad. Cuando en pleno siglo XV el autor describió tal ser que se presentaba contra la las leyes de la naturaleza, tanto él como sus lectores creían en la existencia del monstruo de Ravenna. No obstante, quizás lo que en este punto menos importa es la existencia o no de un ser tal como el que se presenta, ni tan siquiera el hecho de que se creyera en él o no, sino la cuestión de que como el tratado escrito por Luca Landucci se han realizado tantos en todas las épocas históricas, normalmente acompañados de ilustraciones, que cabe reflexionar profundamente sobre una hecho de lo monstruoso en la historia. Es más, tal ha venido siendo la importancia de lo monstruoso para el ser humano, que incluso en ciertas épocas ha habido personas dedicadas profesionalmente al estudio y explicación de la aparición de los hechos

\footnotetext{
${ }^{5}$ LANDUCCI, L., Diario fiorentino dal 1450 al 1516, Sansón, Firenze, 1883, p. 314. Citado por DASTON, L. y PARK, K. (2000), p. 152.
} 
monstruosos. Válgase poner tan sólo aquí el ejemplo del teratólogo, aquella persona dedicada al estudio de las malformaciones, como fue el caso de Geoffroy Saint-Hilaire, el que, en $1832^{6}$ acuña tal término para comprender la tarea de todos aquéllos que en la historia han trabajado en base a tal avatar.

Desde que existe el ser humano, nace la fascinación hacia aquello que maravilla por su carácter incomprensible desde los conocimientos y perspectivas de cada época. La historia, ya lo señalaba Georges Canguilhem ${ }^{7}$, se construye en base a una dicotomía fundamental que rige la mirada. Ésta es la distinción entre lo normal y lo patológico. Qué sea lo normal y qué lo patológico depende del momento y de las condiciones culturales. Pero toda cultura da su definición de qué es lo normativo, y por tanto de qué no lo es. Y este hecho atañe a los diferentes ámbitos del ser humano: estética, patologías físicas o mentales, costumbres, etc. de tal manera que la definición se instala cual estructura ósea en el comportamiento de las personas hacia lo que les rodea.

Si este binomio lo aplicamos a la propia fisiología humana, podemos hacer nacer la ciencia médica y la psiquiatría. Que un ser humano posea un ojo en la rodilla, un cuerno, alas de murciélago o una pata de águila, como ocurría en el caso del monstruo de Ravenna, implica que no es normal, por tanto que es patológico. Y el acercamiento científico al mismo se hace desde tal perspectiva.

La patología no sólo tiene por qué ser física, sino también puede ser mental. E incluso un "trastorno" mental puede dar lugar a la producción de una deformidad física. Leamos a Nieremberg: Peramato escribe que en las Indias año de mil y quinientos y setenta y tres, nació un niño con forma de diablo, de la manera que suele aparecerse a alguno de aquellos bárbaros, con boca, ojos $y$ orejas disformes, $y$ de horrible figura en la frente, dos cuernos, pelos largos, un cinto de carne doblado, con un pedaço también de carne pendiente del, a manera de bolsa, o zurrón, en la mano izquierda una como campanilla, o sonajuela también de carne, al modo de aquellas con que los Indios se convocan para sus bailes, los muslos armados con carne doblada, y blanca. El muslo derecho con uno como cinto, o corona rodeada. Nació este monstruo con esta figura de demonio, por imaginación, y, espanto que del tuvo la madre, por aparecerse assi en los bailes de aquella gente ${ }^{8}$.

Ocurre fijarse en el pequeño detalle de la última frase, en la que alude el autor como causa del nacimiento de Peramato la imaginación maternal, es decir, lo que se consideraba en la historia un trastorno en la fantasía durante el embarazo que daba lugar a nacimiento de hijos híbridos o con deformidades físicas ${ }^{9}$. Esta patología se definía en base a unos mecanismos culturales de control y teorización sobre la normalidad que se instalaban no ya sólo en la estructura ósea, sino psíquica. La madre, así, no podía tener fantasías sexuales de infidelidad, por ejemplo, dado que de ahí, en tanto que eso era considerado algo pecaminoso, nacían seres tales. Fortunio Liceti, en 1616, en estos términos escribió su tratado De perfecta constitutione hominis in utero

\footnotetext{
${ }_{7}^{6}$ Histoire générale et particulière des anomalies de l'organisation chez l'homme et les animaux.

${ }^{7}$ CANGHILHEM, G. (2004).

${ }^{8}$ NIEREMBERG, Curiosa filosofía y questiones naturales en Obras Philosophicas, Madrid, Impta. Real, 1664, tomo III, Fo. 285 v. Citado por SALAMANCA BALLESTEROS, A. (2007), p. 330.

${ }_{9}^{9}$ HUET, M.-H- (1993); TODD, D. (1995); MOSCOSO, J. (2001); BOUCET, P.-G. (1988).
} 
para tratar de describir la normalidad en la mente maternal a la hora de concebir un hijo.

A fin de cuentas la mente era capaz de producir monstruosidad, así como la aparición de la misma era sintomático, desde un punto de vista moral, del hecho de salirse de lo considerado el Bien personal y común, ya sea relacionado con la divinidad o con lo establecido como normal en una sociedad laica: el cuerno [indica] orgullo; las alas, la ligereza mental y la inconstancia; la ausencia de brazos, carencia de obras buenas; el pie de rapaz, codicia, usura y todo tipo de avaricia; el ojo en la rodilla, una orientación moral exclusivamente hacia las cosas terrenales; el doble sexo, sodomía ${ }^{10}$.

La maravilla y la monstruosidad no sólo deben ser interpretadas desde el binomio planteado por Canghilhem entre normalidad y patología. Resulta necesario bucear océanos más profundos. Cabría preguntarse por qué esos dos conceptos acompañan el devenir de la historia. $Y$ en este punto vamos a rescatar a Friedrich Nietzsche en su distinción de los términos de apolíneo y dionisíaco ${ }^{11}$. A pesar de que él centraba el contexto en el ámbito griego, ambos términos se han generalizado desde la historiografía a la hora de interpretar el ámbito de lo histórico (Eugenio Battisti, Jean Starobinski, Peter Burke). Esto es, el quehacer humano ha caminado siempre acompañado por lo racional y lo irracional, lo luminoso y la oscuridad, la ciencia y lo inefable. De esta forma, al igual que ha habido inquietudes que expresaban mediante la cultura los cánones establecidos por una época, también ha habido curiosidades que indagaban sobre lo incomprensible a la Razón. En la Antigua Grecia, Fidias, Mirón, Praxiteles esculpían la belleza establecida por la ausencia de expresión de la vida interior de los personajes. Sin embargo, la escuela de Rodas (Agesandro, Polidoro y Atenodoro) realizaba el Laoconte, máxima manifestación del arte que habla del dolor. Ya Lessing ${ }^{12}$ dio cuenta de tal debate, cuando en 1766 observó que la historia del arte, siguiendo el ejemplo griego, desarrollaba el arte en base a tal bipolaridad. ¿Tiene el arte derecho a expresar los sentimientos? Razón y sinrazón cohabitan. La sinrazón vive a la sombra, considerada de menor importancia, dado que no se adapta a los parámetros que cada época histórica define. Sin embargo, numerosas han sido las personas que han trabajado dedicadas a tal ámbito, desde el pensamiento hasta el arte, pasando por la literatura.

Lo monstruoso podría considerarse como perteneciente a la línea histórica que se instala en la oscuridad, aquélla que camina al margen del canon, y que existe en tanto que éste define normas, costumbres, leyes, que desde el momento de su aparición marcan una frontera con respecto a lo que no se adapta a ellas. Cuanto más luminosa, racional, religiosa y científica sea una época -como es el caso de la Edad Media, el Renacimiento o la llustraciónmás parámetros normativos se definen, más se concibe que se puede llegar a comprender todo lo que nos rodea a través de la Razón, y por tanto más fronteras con lo monstruoso se crean. No olvidemos, por ejemplo, que en el siglo XVI, entre 1504 y 1534 se realizaron siete ediciones del libro Secret de l'hystoire naturalle, de autor anónimo. $Y$ estas fronteras numerosas con la

\footnotetext{
10 Johannes Multivallis Tornacensis Eusebii Caesariensis episcopi chronicon. Citado por DASTON, L., Op. Cit., pp. 155-156.

${ }^{11}$ NIETZSCHE, F. (2005).

${ }^{12}$ LESSING (1990).
} 
oscuridad dan lugar al nacimiento en la imaginación de más seres que no se adaptan a explicación ninguna. Es decir, cuando más se cree que todo puede ser explicado, bien sea por Dios o por el ser humano, más casos se descubren de cosas inexplicables. Tampoco olvidemos que precisamente en 1523 Parmigianino elabora su Autorretrato en espejo convexo, inaugurando con ello el Manierismo, es decir, dando al arte la posibilidad de abarcar un punto de vista diferente al del Clasicismo, un punto de vista que se atreve incluso a plantear la existencia de la belleza más allá del canon clásico.

Por ello, ha sido en la Edad Media, en el Renacimiento y en la llustración donde ha crecido el número de personas dedicadas al estudio de lo monstruoso (Huyghe ${ }^{13}$ ). El miedo a que lo inexplicable desmontara el paradigma de la entera posibilidad de explicación era abisal.

Resulta interesante acercarse a la historia desde este punto de vista, observando los numerosos intentos de explicar la aparición de la monstruosidad siempre en relación con la época. Aristóteles ${ }^{14}$ trató de explicar desde la ciencia natural las deformaciones congénitas o los monstruos imaginarios tales como sirenas, grifos, polifemos, ya que no podía aceptarse en su filosofía que existiesen cosas contranatura. Agustín de Hipona ${ }^{15}$, al hilo de la discusión sobre la existencia de razas monstruosas -ya inaugurada por Plinio-, propone considerar la monstruosidad como manifestaciones de la omnipotencia divina, que trata de recordar al ser humano siempre que no tiene poder con respecto a él, y que en su origen es un ser pecador, por lo que debe recibir castigos esporádicamente ${ }^{16}$. Mientras que Joachim ler Camerarius ${ }^{17}$ los interpreta como signos propuestos por la divinidad para interpretar malos augurios que vendrán.

No sólo han sido intérpretes o explicadores los que se han dedicado a lo monstruoso, sino que han abundado más los observadores, las miradas atónicas que iban recogiendo los casos insólitos conocidos tanto en el pasado temporal como en el espacio completo del mundo: Plinio (Historia natural. S. I), Julius Obsequens (Liber de prodigiis. S. IV), Polidoro Virgilio (De prodigiis. 1531), Joachim ler Camerarius (De ostentis. 1532), Joannes Boemus (Omnium Pentium mores, leges et ritus. 1536), Kaspar Peucer (Commentarius de praecipuis generibus divinationum. 1553), Pierre Belon (Petri Bellonii Cenomani de aquatilibus, libri duo: cum eiconibus ad vivam ipsorum effigiem, chupad ejes potuit, expressis. 1556), Licóstenes (Prodigiorum ac ostentorum Chronicon. 1557), Boaistuau (Histoires prodigieuses. 1567), Ambroise Paré (Des monstres

\footnotetext{
${ }^{13}$ HUYGE (1957).

${ }_{15}^{14}$ ARISTÓTELES, Física, Libro II, Cap. 8. Véase cualquier edición vigente.

15 HIPONA, A. de (2006), XVI, 8-9.

${ }^{16}$ Esta teoría de que el monstruo es un signo de la omnipotencia divina frente a la humanidad perdura largo tiempo durante la historia. Un caso curioso es el que se presenta en 1628, a través de un autor anónimo, cuando trata de explicar el nacimiento en Lisboa de un monstruo con cara humana, pero cuyo cuerpo y cabeza estaban recubiertos por una armadura de escamas. La conclusión a la que llega es Pero allá donde reconozcamos una deformidad en cualquier criatura fabricada por la Naturaleza misma, no tenemos más opción que declarar ad majorem Dei gloriam, lo que es decir que todo es por la gran gloria de Dios, que está en comunicación y simpatía con la Naturaleza misma (Anónimo, La naissance d'un monstre ayant la face humaine, la teste et le reste du corps couvert d'une armure façon d'escailles. Né à Lisbonne ville capitalle de Portugal, le Lundy 10 Avril 1628 et mort le 14 du mesme mois. Avec les noms du père et de la mère...Paris, M. Mordiere, 1628. Citado por WILSON, D. Op. Cit.

${ }^{17}$ De ostentis (1532).
} 
et prodiges. 1573), Caspar Bauhin (De hermaphroditorum monstrosorumque partuum natura. 1604), Schenk (Monstruorum historia memorabilis. 1609), Fortunius Licetus (De monstrorum natura, caussis, et differentiis. 1616), Ulisse Aldrovandi (Monstrorum historia cum paralipomenis historiae omnium animalium Bartholomaeus Ambrosinus. 1642), Guillaume Mauquest de la Motte (Traité complet des Accouchements naturels, non naturels, et contre nature.1765), Isidore Geoffroy Saint-Hilaire, Histoire générale et particulière des anomalies de l'organisation chez l'homme et les animaux o Traité de Tératologie. 1836)...

La dedicación de recolecta de aquellos casos insólitos históricos y presentes de la naturaleza fue dando lugar a la creación de un imaginario en torno a la cuestión de la monstruosidad. Poco importaba ya la verdad del discurso sobre lo monstruoso, o si las miradas-testigo eran sinceras ${ }^{18}$. El papel del espectador quedaba diluido en el tiempo de las reinterpretaciones. La función de verdad conocida, coincidente con una realidad, había quedado relegada a un segundo plano, dado que se presuponía de partida la veracidad de la historia. La importancia queda, pues, en el hecho de la existencia de tal cantidad de voces prolongadas en el tiempo histórico que hablaban de lo incomprensible, que trataban de explicar lo inexpresable.

Es importante tener en cuenta la cuestión de la creación de un imaginario en torno a lo monstruoso, que tantas veces ha sido olvidado, en tanto que tal hecho conectará la monstruosidad con la visión de la alteridad y el nacimiento del discurso en torno a las razas monstruosas de seres humanos.

\section{Precisión: maravilla y monstruo}

No toda maravilla es monstruosa. Por el contrario, toda la monstruosidad tiene en su base la maravilla. La maravilla, además de ser el origen del pensamiento o la filosofía en términos aristotélicos ${ }^{19}$, es todo aquello que nos sorprende porque es nuevo tanto a la mirada como a los parámetros de conocimiento. En el acto de contemplación de la maravilla existe un momento de silencio. La mirada es fija. El cuerpo es carne atónita. Es algo arraigado en las estructuras de pensamiento y en la cultura. Así pues, si consideramos la posibilidad de que la perspectiva existe, y que por tanto es relativa, cualquier cosa es susceptible de crear el fenómeno asombroso que suscita la maravilla (Giacomo da Vitro ${ }^{20}$ ). Podría ser la piel negra algo maravilloso para alguien que no la ha visto nunca, así como la piel blanca para quien nunca la ha observado. La maravilla, por

\footnotetext{
${ }^{18}$ Pero éstos son detalles entregados únicamente a la credibilidad de algunos escritores y pueden, así como las tradicones católicas, ser o no ser creídos. (Licóstenes, Prodigiorum ac ostentorum Chronicon. 1557. Citado por THOMSON, C. J. S. (2001), p. 39).

${ }^{19}$ De hecho, los hombres comenzaron a filosofar, tanto ahora como en el origen, a causa de la maravilla. Aristóteles, Metafísica, 982 b 10-18.

${ }^{20}$ Historia de Oriente: Sabemos que todas las obras de Dios son maravillosas, aunque aquellos que están acostumbrados a observarlas a menudo no son excitados por la maravilla. Probablemente los cíclopes, que tienen un solo ojo, se maravillan de aquellos que tienen dos, así como nosotros nos maravillamos de ellos o de otros con tres ojos. Así como nosotros consideramos los pigmeos enanos, de la misma forma ellos nos considerarían gigantes si observasen a uno de nosotros entre ellos.

Giacomo da Vitro, Libri duo, quórum prior Orientalis, sive Herosolymitanae, alter Occidentales historiae. Citado por DASTON, L. Y PARK, K., op. Cit., p. 35.
} 
ende, nos conduce a cierta sensación placentera de admirar una nueva forma de belleza que va asociada al exotismo en el sentido de aquello que nos llama la atención por el hecho de ser diferente, según la definición de Victor Segalen ${ }^{21}$.

Es, además, independiente de la Razón en las categorías del conocimiento. Pertenece al ámbito de la experiencia imposible de abarcar, de interpretar (Gervais de Tilbury ${ }^{22}$ ). En ocasiones tal imposibilidad de comprensión se concibe como algo diferente al ámbito de la ciencia, así como digno de estudio desde los parámetros asignados a lo maravilloso (Pseudo Alberto Magno ${ }^{23}$ ), otras como algo execrable en tanto que, al escapar a la Razón, se identifica con las pasiones (Giraldo del Galles ${ }^{24}$ ).

En todo caso, los ímpetus de aquellos coleccionistas que en el siglo XVI adquirían manifestaciones de lo maravilloso para depositarlas en sus Wunderkammern y exhibirlas al público no vivían de la misma forma la maravilla como se vive la monstruosidad.

Ésta va asociada a la categoría estética de lo sublime ${ }^{25}$. Nos atrae porque nos aterra. Supera, como la maravilla, nuestro nivel habitual de entendimiento, pero además nos abre a un ámbito oscuro que se cierne sobre la pérdida y la huida. Queremos dar media vuelta ante el monstruo, devenir ciegos hacedores de música.

Así, cada época debe crear sus formas de lo monstruoso, bien sea a través de casos experienciales o de casos imaginarios. A fin de cuentas, definiendo lo que es patológico, como se ha dicho anteriormente, se controla el normal devenir de una sociedad. Todo aquello que es monstruoso se aísla, se estudia, se encierra (Michel Foucault ${ }^{26}$ ).

\footnotetext{
${ }^{21}$ SEGALEN, V. (1978).

${ }^{22}$ Define lo maravilloso como aquello que escapa a nuestra comprensión, aunque sea natural. Citado por LE GOFF, J. (2007).

${ }^{23}$ Algunas cosas deben ser creídas sólo por experiencia, sin la razón, ya que están ocultas a las personas; otras deven ser creídas sólo mediante la razón, porque de eso no tenemos sensaciones. De hecho, incluso aunque no entendamos por qué el imán atrae el hierro, no obstante la experiencia lo muestra, así tal que nadie debería negarlo. Y tal como eso es maravilloso y está establecido como cierto sólo en la experiencia, se debería suponer [que es] igual en otras cosas. No se debería negar ninguna cosa maravillosa porque falte una razón para la misma, sino que se debería experimentar; ya que las causas de las cosas maravillosas están ocultas, y dependen de causas ulteriores tan diferentes que la comprensión humana, como dice Platón, no puede aprenhenderlas. Pseudo Alberto Magno, De mirabilibus mundi, sig. Z8v-aalr.

${ }_{24}$ ¡Cuánto indigno e indecible! ¡Cómo puede la razón sucumbir tan ultrajadamente a la sensualidad! Que el señor de los brutos, perdiendo los privilegios de su noble condición deba descender al nivel de las bestias, jcuando un ser racional se expone a sí mismo a un comercio tan vergonzoso como un animal bruto! [...] Quizás podríamos decir que la naturaleza da cuenta en verso de su indignación y su repudio a tal acto. Giraldo del Galles, Historiy and Topography, 2.56 .

${ }^{25}$ Elevan las fuerzas del alma más allá de su nivel habitual y nos descubren en nosotros la facultad de resistencia de una forma totalmente diferente, que nos ofrece el coraje de medirnos con el aparente carácter todopoderoso de la naturaleza.

KANT, I., Crítica del juicio, 28.

${ }^{26}$ FOUCAULT, M. (2001).
} 


\section{Monstruo, viaje y mirada hacia la alteridad}

De entre las manifestaciones relatadas sobre lo monstruoso, son las que atañen la mirada hacia el otro aquéllas que serán de interés aquí.

El viajero era aquél que partía de su lugar de origen hacia un lugar lejano en el espacio, y que, a su regreso, tornaba con un relato pictórico o escrito sobre su experiencia del viaje ${ }^{27}$. En esa narración ofrecía una visión sobre el otro que pasaba a través de su propia mirada. Y ésta es evidente que estaba construida en base a los conceptos que había heredado de su cultura. De esa forma, la descripción de la alteridad se realizaba en base a unos juicios de partida que podrían llamarse prejuicios. Si el viaje, además, se realizaba a lugares alejados, desde un punto de vista cultural, del viajero, su visión del otro se encontraba todavía más quebrada por el espejo de la propia identidad. Así, numerosas fueron las producciones sobre las costumbres de los orientales, su fisonomía, etc. que en ocasiones obedecían al binomio entre progreso de la cultura de origen y barbarie de la cultura visitada (Edward Said ${ }^{28}$ ). Estos relatos pictóricos o literarios sobre la alteridad fueron creando un imaginario sobre qué es lo que se iba a encontrar en tal o tal otro lugar geográfico, que el conocimiento sobre la alteridad pasaba siempre y ante todo por la visión del viajero, que era considerada un testimonio verdadero.

Entre las miradas fragmentadas hacia el otro, se comenzó a desarrollar una teoría sobre la existencia de razas monstruosas en lugares geográficos alejados. En el prejuicio sobre la alteridad como lugar donde se guarda la barbarie, la deformidad fisiológica era algo que con evidencia se mostraría. Árabes, judíos, seguidores de otras confesiones religiosas, proscritos de la fe verdadera, serían razas en las que de alguna u otra forma la divinidad manifestaría su poder y su rechazo a los infieles con monstruos. Y no ya sólo por el hecho de la religión ajena, sino por el de las propias creencias. Si la divinidad era capaz de manifestar su furia ante el comportamiento humano a través del monstruo, y si las criaturas monstruosas no eran de observación común dentro de la vida cotidiana de los ciudadanos, fácil resultaba relatar la existencia de la misma en lugares alejados a los que las personas no pudieran acceder, pero de los que se tuvieran testimonio a través de los viajes. Así, desde Megástenes con Indika en el siglo IV a. C., pasando por el Romance de Alejandro en el siglo XII, hasta el Libro de las maravillas de Marco Polo en el siglo XIII o el Libro de las maravillas del mundo de John Mandeville en el siglo XIV, escritos leídos por un gran número de personas, se abren tal tipo de disquisiciones.

Tan sólo con acercarse a la representación cartográfica, es decir, a la visión que del mundo se tiene en cada época, podemos observar que en el siglo XIII, por ejemplo, el mundo era circular, presidido por la divinidad, con la civilización concentrada en su centro, y, en los límites con la nada, la barbarie manifiesta a través de las diferentes razas monstruosas (Ebstorf, Hereford, Psalter, por poner escasos ejemplos).

Así, los cinocéfalos, situados por Marco Polo en las islas Andamán y Nicobar y por Mandeville en la isla de Vacumerán, eran una raza con cuerpo humano y

\footnotetext{
${ }^{27}$ Para una visión más detallada ver SORIANO NIETO, N. (2009).

${ }^{28}$ SAID, E. (2003).
} 
cabeza de perro ${ }^{29}$. O los panotios o fanesis, raza de orejas gigantes ${ }^{30}$. También los esciápodas o monoscelos, que poseían una sola pierna con un pie de grandes dimensiones. Los anencéfalos o seres sin cabeza que tenían los ojos en los hombros. Los hermafroditas. E incluso los pigmeos eran considerados una raza monstruosa (Sebastian Münster, Cosmographie universelle. 1565).

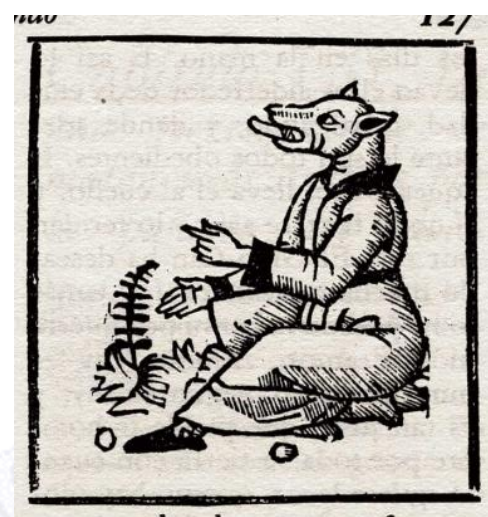

Cinocéfalo. John Mandeville, Libro de las maravillas del mundo

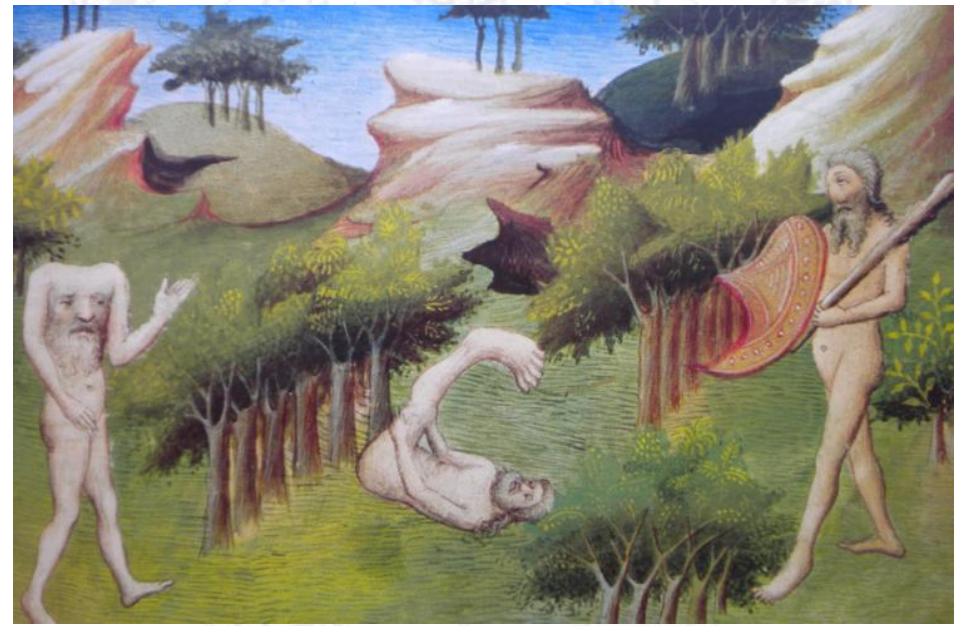

Anencéfalo y Esciápoda. Maestro di Boucicaut. Livre des Merveilles, s. XV. BNF. Paris

El auge de la teorización sobre las razas monstruosas decae más o menos en el siglo XVII, conforme el mundo había sido más explorado. Sin embargo, la

\footnotetext{
${ }^{29}$ Pues en verdad os digo que todos los habitantes de esta isla tienen cabeza de perro y dientes y ojos como los de este animal, y no debéis dudar de esto que os digo, pues puedo aseguraros que sus cabezas son en todo similares a las de los más grandes mastines.

POLO, M. (1983), p. 402.

$Y$ todos los hombres y mujeres de aquesta tierra tienen cabezas de perros y los llaman "canefalles", e son razonables e de buen entendimiento

MANDEVILLE, J. (1984), p. 27.

${ }^{30}$ También escriben de otros, que llaman faneseos, con las orejas tan grandes, que cubre todo el cuerpo con ellas, y que éstos son de muy grandes fuerzas; tanto, que arrancan los árboles de un solo golpe, y pelean con ellos con muy gran ligereza.

TORQUEMADA, A. de (1943), p. 31.
} 
visión sobre la alteridad como algo extraño, maravilloso y monstruoso sigue su curso transformándose. El concepto de raza monstruosa a nivel fisiológico desaparece para brindar más importancia al concepto de barbarie, creándose un debate en torno a la condición de quien se instala en tal categoría.

El concepto de barbarie a partir del siglo XVII va siempre asociado a la alteridad, y son las producciones de los viajeros las que alimentan tan reflexión. Podría decirse que tal concepto es heredero de la teoría del hombre salvaje, desarrollada en el pensamiento occidental a partir de la Edad Media.

El hombre salvaje era representado en la Edad Media como un ser humano normalmente cubierto de pelo, desnudo y acompañado de un bastón. Suele pertenecer a su imaginario la gran fuerza física y la brutalidad, es decir, la ausencia de civilización. Tal figura se construye desde la propia cultura occidental para señalar cómo son y qué ocurre con los seres humanos que no se rigen por la moral y las leyes divinas (Hayden White ${ }^{31}$ ).

Esto es, para el pensamiento medieval, se inaugura una visión sobre la alteridad -lo que vive fuera de las fronteras conocidas- que parte de la base de la inferioridad con respecto a quienes se atañen a las costumbres de la culturización.

En el Renacimiento esta teoría comienza a convivir con otra nueva forma de interpretación. En ella, asociándose el salvajismo al mito de la Edad de Oro, el hombre salvaje es capaz de vivir en un estado de naturaleza -contrario a la cultura- que se considera idílico. Es necesario tener en cuenta que los valores medievales centrados únicamente en la divinidad entran en crisis. La cultura sufre un gran golpe. $Y$ es común entre los ciudadanos preguntarse si no viven mejor aquellos que armonizan con el estado natural (Joan B. Llinares ${ }^{32}$ ). Tal es así, que incluso el estado de naturaleza puede llegar a ofrecernos una lección de posibilidad moral más adecuada que el estado de culturización. Claro ejemplo el de la figura del villano del Danubio, aparecida en la obra de Fray Antonio de Guevara (1529) ${ }^{33}$. Éste, se apareció al emperador Marco Aurelio para realizar una querella frente al Senado y pedir justicia, vestido con su atuendo de hombre salvaje, haciendo ostensión de su condición natural. El impacto en el imaginario de una aparición tal hizo que se regresara en la representación a esa figura por John Bullver o Hans Holbein.

\footnotetext{
${ }^{31}$ WHITE, H. (1972).

32 LLINARES, J. B. (2008).

${ }^{33}$ En el año primero que fui cónsul, vino a Roma un pobre villano de la ribera del Danubio a pedir justicia al Senado contra un censor que hazía muchos desafueros en su pueblo; y de verdad él supo tan bien proponer su querella y exagerar las demasías que los juezes hazían en su patria, que dudo yo las supiera Tullio mejor dezir, ni el muy nombrado Homero escrevir. Tenía este villano la cara pequeña, los labrios grandes y los ojos hundidos; el color adusto, el cabello erizado, la cabeça sin cobertura, los çapatos de cuero de puerco espín, el sayo de pelos de cabra, la cinta de juncos marinos y la barba larga y espessa; las cejas que le cubrían los ojos, los pechos y el cuello cubierto de vello como osso, y un azebuche en la mano.

GUEVARA, FRAY A. de. (1994), tomo II, Libro III, capítulo 3.
} 


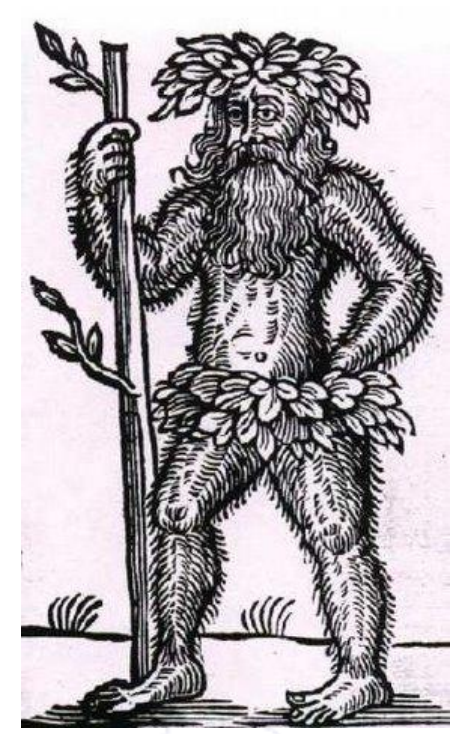

John Bullver. El villano del Danubio. 1653

Este mito del salvaje en su condición positiva es el que llegó en la línea de la historia hasta la figura del buen salvaje, es decir, del estado feliz de naturaleza frente al estado infeliz de cultura, desarrollada fundamentalmente por Rousseau (Discurso sobre las ciencias y las artes. 1750). Esta teoría convivía con la propuesta por Hobbes (Leviatán. 1651), según el cual el estado de naturaleza es un estado de guerras entre los seres humanos, y que la culturización da lugar a poner orden y fin al desastre originario.

El debate sobre el hombre salvaje, como puede observarse, es un tema de especial relevancia durante la Edad Moderna. Lo que más interesa aquí no es el hecho de si eran más las posturas sobre el estado idílico o salvaje de la naturaleza en el ser humano, sino el hecho de que siempre se asociada a la alteridad el estado de salvajismo. Incluso el villano del Danubio, ser humano refinado en el trato con el Senado romano, era alguien de procedencia desconocida ajena a la cultura familiar del que relata la historia.

Esto es especialmente sintomático, en tanto que retomamos la cuestión que nos parece fundamental. En la mirada hacia la alteridad se instala lo monstruoso, lo diferente, la maravilla. Bien sea considerándola en sentido positivo -como en el caso del buen salvaje- o en sentido negativo -como en el caso de Hobbes y la tradición medieval-, es el otro el que tiene costumbres diversas. Es él el que vive fuera de la civilización.

Y esta cuestión no es inocente especialmente en el siglo XVIII, en tanto que se parte de nuevo de un binomio: la separación entre cultura y naturaleza, siendo el estado cultural propio, y el de naturaleza ajeno. Es más, el binomio tampoco es inocente en tanto que en la mayor parte de las ocasiones en el caso de los viajeros del siglo XVIII se parte de la base del estado superior, en sentido de progreso, de la culturización con respecto a la naturaleza. Así, la imagen que se da de lo ajeno por los viajeros va alimentando un imaginario de superioridad de la cultura de origen sobre la alteridad. 


\section{Ilustración, viaje y Grand Tour}

Es precisamente en el análisis del viaje en el siglo XVIII donde especialmente surgen tales disquisiciones sobre la diferencia entre la cultura propia y la ajena. Podríamos decir que los viajeros del siglo XVIII parten siguiendo dos inquietudes fundamentales, que definen dos tipos de destinos geográficos.

En primer lugar, en tal época se tenía una gran curiosidad por observar in situ las grandes obras arquitectónicas, sociales, artísticas de la cultura clásica. La llustración retoma como identidad los orígenes de la civilización occidental. Los que precisamente habían hecho nacer el ímpetu del tipo de pensamiento ilustrado basado en la posibilidad humana de gobernar el mundo en base al ámbito racional que les hacía diferenciarse de los animales, de las bestias, de los salvajes. En este sentido, aparece un gran número de viajeros europeos que en su viaje educativo se dirigían especialmente a Italia con el fin de conocer qué significaba lo Clásico.

En segundo lugar, la otra base de la curiosidad en el viaje se dirigía hacia lugares geográficos alejados en formas y costumbres de la propia cultura de origen. Así, el viaje a Oriente, especialmente al oriente árabe en tal época, comienza a tener un gran número de adeptos que a fin de cuentas tratarán de relatar las diferencias entre la alteridad y el yo entendido como perteneciente a una sociedad de la que parten. Los valores culturales de la llustración, en ese momento, harán contrastar el estado de barbarie de los pueblos ajenos con el estado de cultura y progreso, gracias a la Razón, que se concebía en los pueblos desde los que se partía.

No obstante, antes de entrar a analizar más en detalle tales cuestiones, trataremos de realizar un contexto histórico y de pensamiento general para poder entender tal paradigma interpretativo.

Antes de entrar en el siglo XVIII, la literatura de viajes y su escritura sufren, al igual que el pensamiento general a finales del siglo XVII, una crisis en base a los valores propuestos por el Renacimiento, y que ya se anunciaba a través del arte con el manierismo: la crisis de la conciencia europea (Paul Hazard ${ }^{34}$ ). Finaliza el dejarse llevar por los dogmas y la autoridad, actitud que había sido propia del mundo clásico, se rompe con el equilibro y la estabilidad, siendo ahora necesaria la construcción de una nueva metafísica que identifique la esencia de la vida humana en algo distinto a los dogmas, bien sean originados por una religión, bien por los valores de una cultura laica. De ahí nace, por ejemplo, el intento cartesiano que busca la nueva metafísica basada en primera instancia en la razón.

Es éste un tiempo histórico en el que el gusto por el viaje se desarrolla de forma exponencial. Se trata de conocer lo que está más allá de lo propio, se trata de ver qué existe más allá para poder juzgar qué es lo adecuado o: Si usted es curioso, viaje $e^{35}$. Esta posibilidad de relativizar lo dogmático ya había sido planteada por la doctrina luterana al abrir la posibilidad al sujeto de leer directamente los textos sagrados.

\footnotetext{
${ }^{34}$ HAZARD, P. (1995)

${ }^{35}$ CHÉTARDIE, T. de la, Instructions pour un jeune Seigneur, ou l'idée du galant homme, Paris, 1683, p. 68. Citado por HAZARD, P., ibid.
} 
Tal crisis era ya predecible un siglo atrás. A finales del Renacimiento convivían posturas de pensamiento diversas, contrarias, antinómicas, que tarde 0 temprano anunciarían la muerte de la creencia en los dogmas. Tomamos palabras de Haydn: Entre la mitad del siglo XIV y comienzos del XVII se pueden distinguir tres grandes y diferentes tendencias de pensamiento. La primera de ellas es el clasicismo renacentista, o renacimiento humanista; la segunda, que defino Atirrenacimiento, surgió como protesta contra los principios fundamentales bien sea del clasicismo o de la escolástica medieval. Pero naturalmente también el Antirrenacimiento forma parte, desde un punto de vista cronológico, del Renacimiento. El tercer movimiento, liderado por Galileo y Kepler, podría mejor definirse como "reforma científica". Estas tres corrientes se suceden una tras otra cronológicamente en el orden en el que las hemos expuesto. En tanto que compenetran toda la vida y la cultura de la civilización occidental, maduran lentamente de modo orgánico y se combaten entre ellas, incluso cuando tocan el ápice de su evolución $n^{36}$.

Los escritores ponen su centro de atención en los escritos de viajes, como La terre australe connue, de Gabriel de Foigny (1676) o l'Histoire des Sévarambes, de Denis Veiras, publicada entre 1677 y 1679.

En el siglo XVIII, el mundo empieza a entenderse como un espacio regido por leyes absolutamente comprensibles y cognoscibles para el ser humano. Cabe recordar que Newton proporcionó formas lógicas y sencillas de entender los fenómenos del mundo.

Fue Kant el que en “¿Qué es la llustración?”37 definió tal forma de pensamiento de la cultura ilustrada. Ser ilustrado era una forma de vida, un paso de la adolescencia de pensamiento a la Razón. Es así cómo, ante el triunfo del mecanicismo y de la razón, se comienza a dar forma a esa llamada por instrumentalización del lenguaje, que no es más que el reflejo de una instrumentalización del mundo por parte del sujeto.

En este sentido es como el viaje empieza a convertirse en una forma muy importante de contacto con los objetos, con el mundo, con lo nuevo, dando puerta abierta a este uso de la Razón, clasificatoria en el naturalismo imperante.

Sin embargo, con dicotomías y binomios, en el siglo XVIII no sólo existe tal tendencia a entender el mundo desde lo racional. A la sombra, como en cada época histórica, la Razón convive con lo irracional, y existe una forma de pensamiento que abraza entre los propios ilustrados la parte menos luminosa del mundo (Javier Moscoso ${ }^{38}$ ). Claro ejemplo lo constituye la reflexión filosófica del Marqués de Sade a través de su literatura o el auge de la teratología como ciencia médica. También es sintomático de la convivencia entre lo racional y lo irracional en el Siglo de las Luces la relación que tienen los intelectuales con la monstruosidad. Partiendo de la base de que lo monstruoso forma parte de la línea de sombra de la Historia, los llustrados trataron de realizar una catalogación y clasificación de las tipologías de los mismos, como un ímpetu para dar luz a ese territorio de lo no explicado, y, por ende, no comprendido. Tal es el caso, por poner un ejemplo, del embriólogo Caspar Friedrich Wolf

\footnotetext{
${ }^{36}$ HAYDN, H. (1950), pp. XI-XII.

${ }^{37}$ KANT, I. (2004).

${ }^{38}$ MOSCOSO, J. (2000).
} 
(1734-1793), quien en su Theoria Generationis (1759) clasifica las malformaciones de la generación en Monstruos particulares, Monstruos bicéfalos, Pipópagos -o unidos espalda con espalda-, Craneópagos -o unidos por el craneo-, Monstruos parásitos en los que crece otro cuerpo y Tricéfalos ${ }^{39}$. Así, poco a poco, el discurso sobre lo monstruoso va siendo arrastrado por el ímpetu clasificatorio, hasta que se convierte en una ciencia médica, la teratología ${ }^{40}$.

En cuestión del gusto estético -que nos servirá aquí para interpretar la producción de los viajeros-, surge una gran pasión hacia la sensibilidad en tanto que procedente de la subjetividad humana arraigada en el deseo. Lo bello, así, está en aquello que produce un sentimiento de placer en el sujeto que siente. (Addison ${ }^{41}$, Shaftesbury y Hutcheson, Hume).

A tal reflexión estética cabe añadir, siguiendo la línea de la sombra, la teoría de lo sublime desarrollada con especial energía por Kant, en base a los presupuestos definidos por Edmund Burke en su Philosophical Enquiry into the Origin of our Ideas on the Sublime and the Beautiful (1757). Esta se encuentra especialmente relacionada con el ámbito de lo monstruoso. Para Kant lo sublime se presenta en la experiencia estética del sujeto en el momento en el que el objeto que aparece desborda la facultad humana de la intuición, con la que se capta la experiencia estética. Esta inadecuación produce inmediatamente en el sujeto un terror, el cual es conocido a través de la categoría de "sublime" proporcionada por la Razón. El hecho de categorizarlo permite dominar el objeto que nos provocaba terror. Esta aprehensión da lugar a la aparición de un placer negativo hacia el objeto, que a un tiempo nos atrae.

La Razón da al viaje un carácter cada vez mayor de apropiación de la alteridad, en la medida en que el sujeto que viaja, perteneciente a una sociedad que parte del presupuesto de haber salido de la adolescencia del pensamiento medieval mágico y totalizante, debe mostrar y educar al Otro para que pueda también salir de esa época de ignorancia. Es necesario introducir, desde el punto de vista moralizante de esta Razón ilustrada, el punto didáctico del viaje: Viajar por viajar es errar, ser vagabundo; viajar para instruirse es todavía un

\footnotetext{
${ }^{39}$ Cabe remarcar, sin entrar de lleno a este tema aquí, ya que desviaría el argumento, que una de las razones por las que se necesitaba clasificar lo monstruoso en el caso de los nacimientos humanos, era para comprender cómo tratar a esos sujetos desde el punto de vista legal. Que dos cuerpos siameses se consideren dos personas requiere un tratamiento diferente jurídicamente que si se considera un solo cuerpo. -a efectos de herencias y otros reconocimientos-. Esta discusión es central en la obra de Isidore Geoffroy St-Hilaire (Traité de Tératologie. 1836), quien retoma la publiación del Dr. Riolan (De monstro nato Lutetiae Anno Domini 1605. Die 17. Mensis Januarii. Disputatio philosophica per Joannem Riolanum Fil. D. M. Annat. \& Pharm. Profess. Reg. Parisiis. Apud Oliviarium Varennaeum, via Jacobaea, sub signo Victoriae) sobre el nacimiento de dos gemelos siameses, para preguntarse sobre la posesión de una o dos almas, y para cuestionar si tal ser/es deben ser destruidos desde su nacimiento.

${ }^{40}$ El término "teratología" fue introducido por primera vez Isidore Geoffroy St-Hilare en su Traité de Tératologie (1836). Él utiliza el término griego Teras, en lugar del latino Monstrum, para denominar a lo que él en su propio libro considera el tercer periodo en la historia de la monstruosidad. Este tercer periodo comenzó en el siglo XVIII y se prolongó hasta la época en la que él vivió, y se caracteriza por haber convertido la monstruosidad en una ciencia. Los dos periodos anteriores no estaban más que caracterizados por la curiosidad, la observación, la superstición y los prejuicios.

${ }^{41}$ Precisamente Addison realizó un viaje por Europa entre 1701 y 1703, del que publicó en 1705 su Remarks on Several Parts of Italy. En él hace referencia especial a lo que podríamos considerar una noción de lo sublime durante el viaje.
} 
objeto demasiado vago: la educación que no tiene un fin determinado no es nada ${ }^{42}$.

Existe, en este sentido, en el viajero ilustrado una conciencia de la propia "superioridad" con respecto al otro en las cuestiones científicas, artísticas, evolutivas... Así, en el viaje a lugares donde habita la alteridad el viajero debe poder hacer que esos otros salgan de ese tipo de pensamiento atrasado. Por ejemplo, el Voyage en Égypte et en Syrie de Volney, supone una apropiación de la alteridad. Así como la Description de l'Égypte, realizada a partir de la expedición de Napoleón a Egipto en 1798. En tal viaje se enviaron intelectuales que permitiesen conocer y describir el Egipto antiguo mejor que los propios habitantes de esas tierras, lo cual, en la medida en que es una apropiación de la historia de los otros, es una forma de colonización algo más silenciosa y potente que la de las armas.

No obstante, el tema fundamental en el que nos vamos a centrar llegados a este punto es en el viaje despertado por la curiosidad de los valores de la cultura clásica, es decir, el viaje a Italia durante la llustración.

Uno viene a Italia para observar los edificios, esculturas, pinturas, la gente. (Hester Lynch Thrale Piozzi. 1789 ${ }^{43}$ ).

Grand Tour es un término que hace referencia concretamente al viaje a Italia emprendido por los burgueses (Werner Sombart ${ }^{44}$ ) como una forma de cultivo del espíritu tras los estudios superiores en el país de origen. Y el espíritu es educado a través de la observación y el aprendizaje. Cuál mejor, pues, que el que nos vierte los restos de una cultura completa en su desarrollo artístico como fue la de la Antigüedad greco-romana. Así pues, los espíritus en proceso de conocimiento tenían una obligada visita para su formación a un lugar donde existiesen manifestaciones de tal tipo.

Las condiciones de tal viaje ya habían sido definidas por Francis Bacon en su Of travel (1615): Si quieren que el joven aprenda lo máximo posible durante el viaje, deberían comportarse de la siguiente forma. En primer lugar, él debe conocer un poco la lengua del país al que se dirige; seguidamente debe tener un siervo o tutor como guía en el país. Denle un libro que describa los países que visitará; hagan que tenga un diario. Hagan que no esté demasiado tiempo en un país o una ciudad: eso contribuirá a hacerlo más práctico en la ciudad, y que frecuente el mejor ambiente de la ciudad donde se encuentra; consíganle cartas de presentación para las personas que viven en el país que visita: éstas le servirán para facilitarle las visitas que le interesan. Otro hecho importante es hacerle conocer al séquito de los embajadores ${ }^{45}$.

El viaje del Grand Tour se desarrolla fundamentalmente en el siglo XVIII, porque, como se apuntó anteriormente, el espíritu ilustrado tiene especial predilección por conocer las fuentes de la propia cultura, que se entendía comúnmente en términos de Razón y progreso. Se concebía que es de la cultura greco-romana de donde surgió una línea de pensamiento que, aunque

\footnotetext{
${ }^{42}$ ROUSSEAU, J.-J. (1961), p. 580.

Voyager pour voyager, c'est errer, être vagabond; voyager pour s'instruire est encore un objet trop vague: l'instruction que n'a pas un but déterminé n'est rien.

${ }^{43}$ PIOZZI, H. L. Th. (1967), p. 86.

${ }^{44}$ SOMBART, W. (1998).

${ }^{45}$ BACON, F., Of travel (1615). Citado por SETA, C. de (1992), p. 61.
} 
tuvo su proceso dialéctico dentro del "progreso" histórico $\left(\right.$ Hegel $\left.^{46}\right)$, había llegado a un punto álgido con el pensamiento ilustrado, que pretendía desarrollar la Razón también en el ámbito político -tal fue la base de la Revolución de 1789-. Entender la llustración es imposible si no se hace alusión a este ímpetu que transportó a tal número de personas.

Es decir, el viaje del Grand Tour se realiza con una finalidad identitaria a la base. Esto es, el viajero tras sus estudios se va para conocer las fuentes de su cultura, es decir, para rescatar, afianzar y afirmar la memoria de Europa (Eric J. Leed $^{47}$ ). En ocasiones, incluso, tanto conocía de antemano lo que iba a ver, que el viajero llega a expresar la falta de asombro al encontrarse sobre el terreno: No tuve pensamiento del todo nuevo: nada he encontrado por entero desconocido; mas lo viejo está de tal manera dispuesto, viviente y agrupado, que puede valer por nuevo (Goethe) ${ }^{48}$.

Con todo, el primer viaje que puede reconocerse como prototipo de los realizados en el Grand Tour (Edward Chaney ${ }^{49}$ ) fue el que llevó a cabo Thomas Hoby (1530-1566), quien tras sus estudios en Cambridge realizó un viaje por Florencia, Roma, Nápoles, Calabria y Sicilia. Aunque no todos los criterios de los investigadores sobre cuál es el precursor del Grand Tour están unificados. Podría identificarse a Andrew Boarde como el primer viajero a Italia que viaja de forma laica en 1547 (Cesare de Seta ${ }^{50}$ ).

Y la que podría ser considerada la primera guía de viajes completa sobre Italia fue la realizada por Richard Lassels en 1654 tras sus cinco viajes a Italia, y que fue traducida posteriormente tanto al francés como al alemán (Description of Italy. Póstumamente se publicó en 1670 su Voyage or a Complete Journey through Italy). Precisamente es en esta guía de viajes cuando el término Grand Tour -utilizado por primera vez por Lord Granborne en su viaje a Francia de 1636- adquiere la legitimidad intelectual: Ningún hombre entiende a Livio y César, Guicciardini y Monluc, como aquél que ha hecho precisamente el Grand Tour de Francia y el Giro de Italia ${ }^{51}$.

El destino geográfico fundamental en el XVIII no fue Grecia, a pesar de que la cultura griega fue anterior a la romana, y modelo de ésta. Las condiciones históricas de Grecia en tal época no hacían identificar tan claramente su presente con su pasado. Es decir, en tanto que Grecia pertenecía al Imperio otomano, y, por tanto, estaba en manos de otro tipo de cultura basada en una religión diferente, los restos clásicos no se podían ya interpretar como revividos o habitados de igual forma en una cultura presente. Grecia en ese momento se convertía en un viaje a Oriente.

Así pues, fue Italia el lugar predilecto para realizar el periplo del Grand Tour por las mismas razones que Grecia no lo fue. A fin de cuentas, Italia seguía siendo, para la mentalidad ilustrada de la época, una cultura que había logrado seguir la línea luminosa o racional de la historia hasta su presente en la época -

\footnotetext{
${ }^{46}$ HEGEL (2006).

${ }^{47}$ LEED, E. J., "Memoria e ricordo: il ruolo dei dipinti nel Grand Tour in Italia" en SETA, C. de (ed.) (2001).

${ }^{48}$ GOETHE (1891), Roma 1ำ de Noviembre de 1786.

${ }^{49}$ CHANEY, E. (1997).

${ }^{50}$ SETA, C. de (1992).

${ }^{51}$ LASSELS, R. Citado por Yves Hersant en "'Grand Tour" e Illuminismo" en SETA, C. de (ed.) (2001), p. 21
} 
Renacimiento, Barroco, Manierismo, etc.-. Y en cada pequeño rincón de un país tal podían observarse tales atractivos, siendo Venecia, Roma, Nápoles y Sicilia los más recurrentes.

Dentro de los citados, Sicilia adquiere un interés especial que hace crecer el número de visitantes a la isla. En ella podían observarse restos de la civilización romana, así como numerosos restos de la griega -Magna Grecia-: Naxos, Megara Hyblaea, Catania, Gela, Segesta, Selinunte, Agrigento, Siracusa, Tyndaris.... Es decir, acercarse a Sicilia suponía en cierta medida suplir la carencia del viaje a Grecia que no se realizaba por los detonantes antes expuestos.

Con respecto al viaje a Sicilia existen, desde mi punto de vista, dos modelos de escritos de viaje, y, por tanto, dos formas de plantear el viaje a tales tierras. La primera tiene que ver con el criterio de la objetividad -bien clarificado y definido por la llustración en sus parámetros de la racionalidad-. Este tipo de viaje es fundamentalmente descriptivo, y no tiene como intención nada que no sea la formalización total de lo desconocido, para hacerlo claro al conocimiento. Tal tipo de viaje en el siglo XVIII lo inaugura Jean-Philippe d'Orbille, quien recorrió la isla en 1727 para en 1764 publicar el Jacobi Philippi d'Orville Siquila; quibus Siciliae veteris rudera illustrantur, donde se describen los monumentos de Sicilia, y en el que se incluyen diversas planchas de grabado para ejemplificarlos. A esta tendencia se unió Joachim Winckelmann, quien en 1759 publicó su libro Anotaciones sobre la arquitectura de los antiguos templos de Agrigento en Sicilia (Anmerkungen ubre die Baukunst der alten Tempel zu Girgenti in Sicilien). Winckelmann es arquitecto de formación. Por ende, plantea su escrito de viaje a Sicilia desde el punto de vista de la arquitectura canónica de la época. Para él el interés que tiene la isla no es más que el de estudiar las proporciones de la Grecia Antigua en sus construcciones, así como las particularidades del orden dórico siciliano. Así, centra su estudio en la ciudad de Agrigento. Resulta curioso remarcar que Winckelmann nunca osó dirigirse personalmente a Sicilia, sino que plantea su estudio en base a mediciones que otros habían realizado con anterioridad a él. Es más, envía posteriormente a un joven Johann Hermann von Riedesel, arqueólogo de formación, para verificar su teoría sobre el orden dórico siciliano. Así, en 1767 Riedsel se dirigió a la isla, y de su viaje, que seguía la mirada winckelmanniana, sale publicado en 1771 el Viaje a Sicilia y la Magna Grecia (Reise durch Sicilien und Gross Griechenland).

Pero el modelo winckelmanniano es cuestionado en 1770 cuando Patrick Brydone, viajero escocés, publica su $A$ tour through Sicily and Malta, que tuvo un éxito grande en el contexto europeo, siendo traducido a diferentes lenguas en 1774 se tradujo al alemán y en 1775 al francés-. La diferencia entre Brydone y Winckelmann es que aquél añadió a la inquietud arqueológica y científica el ámbito poético ilustrado del burgués que ha conseguido cultivar su espíritu con la vivencia de la cultura de la Antigüedad. Y ello se puede observar desde el propio planteamiento de la escritura de la obra, que es en forma de diario.

Desde ese momento, se introduce una pasión por el viaje del Grand Tour prolongado hasta la isla de Sicilia, vivido desde los términos literario-estéticos planteados por Brydone. En 1772 William Young publica veinte ejemplares de su A Journal of a Summer's Excursión by the Road of Montecassino to Naples, and from there over all the Southern Parts of Italy, Sicily and Malta in the Year 
1772 de William Young. En 1776 Jean Houel, pintor francés, entra en Sicilia, anotando en su cuaderno de viajes lo que posteriormente constituirían los cuatro volúmenes de su Voyage pittoresque des îles de Sicile, de Malte et de Lipari. Entre 1776 y 1777 Richard Payne Knight realiza su viaje a Sicilia, publicándolo posteriormente Goethe como suplemento a su obra Philipp Hackert. La vida bajo el título Expedition into Sicily. Henry Swinburne viaja entre 1777 y 1778 y escribe su Travels into the two Sicilies. El naturalista Michael Johann de Borch, en 1777, escribe su Lettres sur la Sicile et sur l'île de Malthe que dice sirve como complemento para el viaje de Brydone. En 1780 publica Roland de la Platière su Lettres écrites de Suisse, d'Italie, de Sicile et de Malte. Entre 1781 y 1786 Saint-Non publicó su Voyage pittoresque ou Description des Royaumes de Naples et de Sicile ${ }^{52}$. O Goethe comienza su viaje a Italia en 1786, acompañado del vedutista Christoph Heinrich Knight, visitando Sicilia en 1787. De ahí surgió la publicación de Italianische Reise, por poner escasos ejemplos. En 1790 Friedrich Münter saca a la luz su Nachrichten über beide Sizilien. En 1792 se publica el libro de Brian Hill Observations and remarks in a journey through Sicily and Calabria, in the year 1791.

Tiempo después, ya más adelante en la historia, fuera de la época de los viajeros del Gran Tour, en 1815 el viajero inglés George Russell realiza su viaje a Sicilia, del que surge el libro A tour through Sicily in the year 1815, en 1828 se publica el libro de Louis Simond Voyage en Italie et en Sicile, en 1835 el de M. D.-D. Parjasse L'Italie, la Sicile, les îles éoliennes, l'île d'Elbe, la Sardaigne, Malte, l'île de Calypso, en 1842 Alexandre Dumas publicó Le Spéronare, en 1853 aparece el libro de William Henry Bartlett Pictures form Sicily y en 1856 y 1883 aparecen respectivamente las dos obras sobre Sicilia de Paul de Musset Voyage pittoresque en Italie y En voiturin. Voyage en Italia et en Sicile.

\section{Sicilia: Clasicismo y Monstruosidad}

Como ya se apuntó anteriormente, la búsqueda de los viajeros ilustrado en Sicilia, a priori, se centraba en torno a lo clásico. El escrito de Winckelmann se convierte, así, en un forma a seguir a la hora de acercarse en la mirada hacia la Antigüedad.

No obstante, la forma de interpretar la Antigüedad en Sicilia queda marcada por el binomio anteriormente planteado entre el prototipo de viaje a la Winckelmann y el prototipo a la Brydone.

Tal hecho no quiere significar que Winckelmann se preocupara por lo Antiguo y Brydone no, sino que el primero lo hacía de una forma canónica, y el segundo de una forma pintoresca. Brydone, y los escritores sucesores que siguen su modelo, entre los que se encuentra Goethe, sigue el paradigma de estudiar la arquitectura Antigua planteado por Clérisseau, viajeros y arquitecto francés y acuarelista que viajó a Italia -aunque no llegase a Sicilia-. Clérisseau se formó

\footnotetext{
${ }^{52}$ Resulta necesario remarcar que el Abée de Saint-Non no es más que el coordinador de la edición y publicación. Jean Benjamin de la Borde, perteneciente a la corte de Louis XV, le realizó tal encargo. Él eligió a Dominique Vivant Denon como viajero y escritor, y para ilustrar el libro eligió a algunos becarios de la Académie Française de Roma, como Desprez, Renard o Châtelet. Cuando realizó la publicación, el nombre de Dominique Vivant Denon no apareció en ningún lado. Por tal situación, Vivant Denon decidió publicar su texto firmado como anexo a la traducción del de Henry Swinburne.
} 
en la Académie Française en Roma -donde tuvo un encuentro con Winckelmann, para curiosidad del lector-. Él trataba la Antigüedad desde lo que se ha llamado el "ruinismo" ${ }^{3}$, es decir, veía el interés de la misma no en la reconstrucción del modelo clásico en el presente -como pretendía Winckelmann, o el grabadista italiano Piranesi-, sino en la vivencia de los restos de ese pasado como parte de un presente que los mira de forma melancólica ${ }^{54}$.

Nunca en la vida se nos ofreció el placer de disfrutar de una tan espléndida visión de primavera como la de esta mañana al salir el sol. En el alto claro de la acrópolis originaria surge la nueva Agrigento, en un cerco de suficiente amplitud como para contener en él a los habitantes. Desde nuestras ventanas la mirada se abre hacia la grande y larga llanura de la ciudad antigua, todo jardines $y$ viñas ${ }^{55}$.

En este sentido, el viaje hacia la Antigüedad comienza a mezclarse para los viajeros ilustrados del Grand Tour con la fantasía. Es decir, comienzan a compaginarse los modelos de Winckelmann y Clérisseau como arquitectos. Objetividad e imaginación se dan la mano, porque, como se ha defendido anteriormente, la llustración como época de las Luces se alimentaba a su vez de las Sombras. Es por ello que, a pesar de la importancia del clasicismo en los viajeros del Grand Tour a Sicilia, querríamos traer a colación aquí la igual centralidad de la visión y la atracción hacia la monstruosidad que se presenta a tales viajeros. Esta visión de la oscuridad es una forma de atracción, curiosidad y ámbito de estudio para lo incomprensible o inabarcable por las categorías de conocimiento humano. En la mayor parte de las ocasiones, el peso de la cultura de origen hacía que se desbordasen bien moral, epistemológica o estéticamente ante los lugares de la monstruosidad. Sin embargo, el debate era el comienzo. Tratar de buscar palabras para lo inefable.

Los viajeros, así, también visitaban Italia atraídos por la curiosidad de la costumbre del cicisbeísmo, la existencia de castratos como forma de vida dedicada a la música, el lesbianismo o la fisiología intergenérica -hermafrodita56 .

O también atraídos por la inexplicable e indomeñable experiencia de escuchar el latido del corazón al pie de un volcán. La obra culminante sobre tales sensaciones fue el estudio llevado a cabo por William Hamilton en su Campi Phlegraei. Observations on the Volcanos of the Two Sicilies (1789).

Jean Houel dice del Etna: Siguiendo gradualmente el orden de las operaciones de la naturaleza, haremos conocer este magnífico fragmento de historia natural, si se nos permite hablar así: es el más rico, el más abundante, el más variado, el más sorprendente que la naturaleza nos pueda ofrecer ${ }^{57}$.

\footnotetext{
53 LUI, F. (2006).

54 En este sentido podríamos decir que es precursor del Romanticismo en la forma de la mirada. Goethe también observará la Antigüedad desde ese prima.

${ }^{55}$ GOETHE (2009), Girgenti, martedì 24 aprile 1787.

${ }^{56}$ AAVV (2009).

57 HOUEL, J. (1781), vol. II, p. 56.
} 


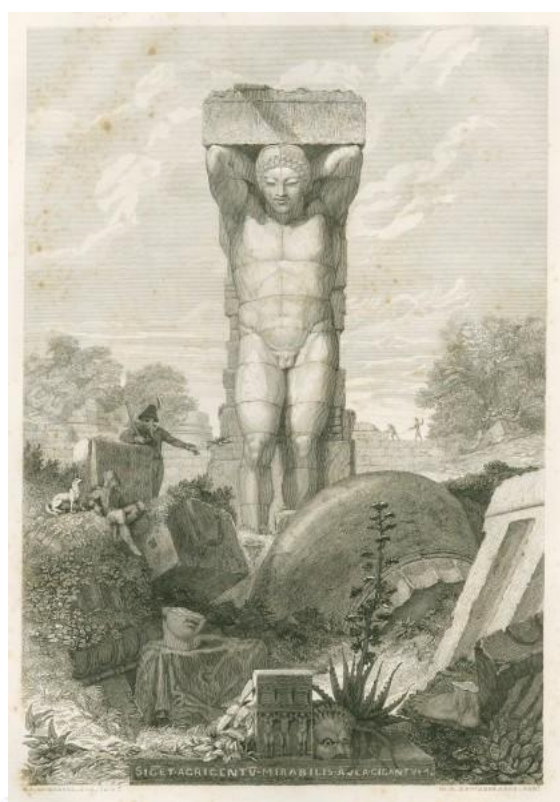

Charles Robert Cockerell. Temple of Jupiter Olympius, Agrigento.

RAA. London

Incluso desde un punto de vista arqueológico, arquitectónico o literario, eran capaces de sentirse desbordados -sublime- por la incomprensión categórica sobre la utilización de elementos monstruosos dentro de la misma cultura clásica. Tal es el caso de los telamones que servían de columnas en el templo de Júpiter Olímpico en Agrigento. Cuando Winckelmann establece las medidas de tales templos, en su escrito sobre Sicilia, lo hace siguiendo la teoría preestablecida de que la belleza en la Antigüedad griega se debía al hecho de seguir la proporción. Pero tales medidas fueron desmitificadas desde el mismo viaje de Riedesel a la isla. Uno de los grandes problemas a la hora de continuar con la teoría sobre la belleza proporcional clásica es la existencia de los telamones. Éstos, monstruosos en su naturaleza por sus gigantescas dimensiones, hacen pensar a cierto tipo de viajeros en la existencia también en la época griega de esa dicotomía entre lo racionalizado y lo monstruoso. El mismo Goethe dice: Ese templo, como otras grandes construcciones griegas de aquella época, no fue nunca terminado. El espíritu valiente de los antiguos se giraba siempre hacia lo sublime, pero no siempre tuvieron la constancia para llevar a cabo sus planos gigantescos. ${ }^{58}$ Para los griegos, según palabras de Goethe, y siguiendo la tendencia de pensamiento que recogió cual manifiesto el Laoconte de Lessing, el arte tiene derecho a expresar algo más que la belleza proporcionada.

El propio clasicismo marca los límites del concepto que se impone a la belleza clásica. El viajero que pasa por Sicilia en el siglo XVIII experimenta tal intuición, aunque en la mayor parte de las ocasiones su propio sistema de conocimiento no puede apropiarse, por las condiciones históricas, de tal vivencia. En el momento en que la experiencia de lo inapropiable por el conocimiento se lleva a su extremo más radical, aparece la monstruosidad en la experiencia del viajero.

${ }^{58}$ GOETHE (1988). 
En el mismo siglo XVIII, siglo de la Razón, Ferdinando Francesco II Gravina Cruylas et Alliata, príncipe de Palagonia, decoró una de las villas de la ciudad de Bagheria (Sicilia), la villa Palagonia con un jardín de esculturas monstruosas: Escandaloso, monstruoso, absurda injuria [...] Burla de Sicilia, los visitantes de los siglos XVIII y XIX se indignaban Amorosos del espíritu griego antiguo, venían de toda Europa en esa tradición del "viaje a Italia" para contemplar las columnas de Segesta y Agrigento, testimonios del orden y la armonía clásica; eran pintores, escritores, intelectuales o aristócratas y tenían por nombre Goethe (cuyo Fausto acababa de ser publicado); Houel, paisajista de Rouen; Swinburne, barón inglés... Pero a raíz de la publicación del Viaje a Sicilia y Malta de Patrick Brydone en 1770, tenían curiosidad por recorrer las afueras palermitanas para llegar a la pequeña ciudad de Bagheria, en la que ricas familias sicilianas habían establecido su residencia. Ninguna palabra del vocabulario del siglo XVIII se podía aplicar para circunscribir la "locura" del príncipe de Palagonia en una categoría arquitectónica, ya que en esa época lo Bella era antinomia de la Fealdad ${ }^{59}$.

\subsection{Bagheria y la Villa Palagonia}

Bagheria fue creciendo, cercana a la ciudad de Palermo, como espacio en el que las grandes familias sicilianas construían sus estancias de recreo para salir del universo consuetudinario. En las ville cada uno utilizaba su máximo potencial monetario y artístico, contratando a los arquitectos más conocidos de la época. Desde la construcción del Palazzo Butera en 1658 por parte de Giuseppe Branciforti, príncipe de Pietraperzia e Leonforte comienza esa tendencia en una ciudad que va creciendo de la forma descrita. En el diseño de los palacios iban retomándose todos los conceptos del gusto de distintas épocas. Entre otras, el palazzo Butera retomaba el gusto medieval, la villa Valguarnera, mandada construir por Maria Anna di Gravina principesa de Cattolica en 1712, y finalizada en 1783 recogía el gusto del Neoclasicismo o la villa San Cataldo, realizada para la familia de los príncipes de Galletti di San Cataldo, terminada a finales del siglo XVIII, fue decorada en estilo Neogótico.

La construcción de la villa Palagonia comenzó en 1715, por iniciativa de Ferdinando Francesco I Gravina, tío de Ferdinando Francesco II Gravina Cruylas et Alliata (1722-1788). Ferdinando Francesco I encargó al arquitecto Tommaso Maria Napoli el diseño de la misma, y éste contrató, a su vez, a otro arquitecto, Agatino Daidone. Cuatro generaciones participaron en la construcción de la villa. Tres de ellas según las reglas del Barroco, y la cuarta que siguió el Neoclasicismo. De hecho, la propia construcción habitacional está realizada en base a las reglas canónicas de la época: simetría en la planta, simetría en el proyecto y en las aperturas, cuerpo central rodeado de cuerpos base para acoger a la servidumbre, escalones de acceso a la planta noble, cromatismo en la fachada.

${ }^{59}$ BOUCHART, F.-X. y BEAUTHÉAC, N. (1982). 


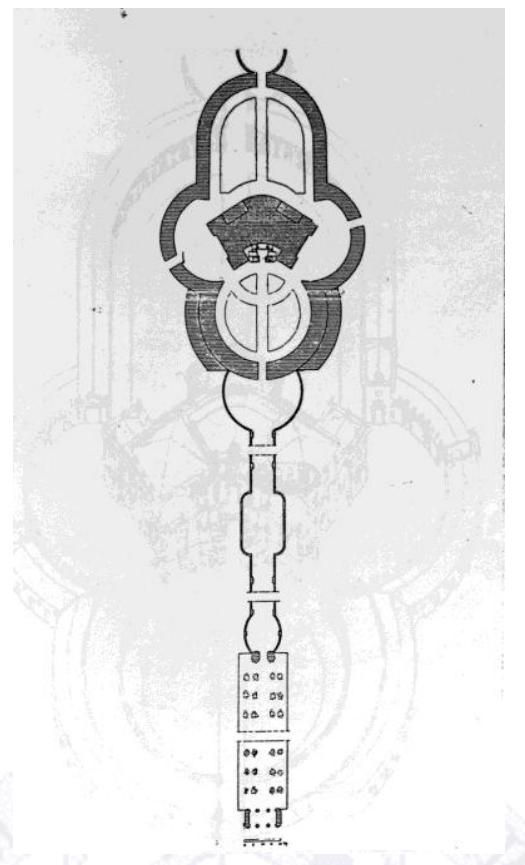

Representación de la planta de la finca de Villa Palagonia, Incluyendo el paseo de acceso y el espacio habitacional.

Fuente: Natale Tedesco.

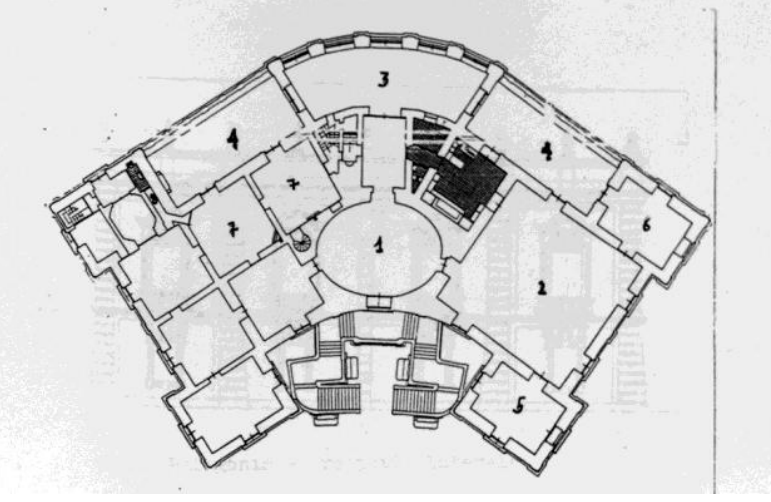

Planta del espacio habitacional de la Villa Palagonia ${ }^{60}$.

Fuente: Natale Tedesco y Rita Cecala.

No obstante, el punto interesante de la villa Palagonia lo puso Ferdinando Francesco II cuando en 1746 la decoró con contrapuntos al Neoclasicismo que se había establecido como primario en la composición de la villa. Así, él mismo en una inscripción mandada realizar en el acceso a los dormitorios, dice: Cangiò l'antica interior struttura al gusto di una moderna architettura. [Cambió la antigua interior estructura al gusto de una moderna arquitectura].

\footnotetext{
${ }^{60}$ Siendo el 1 el vestíbulo, el 2 el Salón de los Espejos, el 3 el salón comedor, el 4 terrazas, el 5 la capilla, el 6 la sala de billar y el 7 los dormitorios.
} 
El conde De Borch nos narra cómo resultó el proceso de cambio de los estilos, aunque no fue exactamente el padre el que realizó el primer proyecto -como narra De Borch, sino el abuelo, ya que su padre falleció tempranamente-: El padre del Príncipe, hombre sensato \& amante de sus comodidades, habiendo elegido un lugar agradable construyó en él un bello palacio que adornó con estatuas, bustos de hombres importantes, cuadros de familia \& muebles caros: después su hijo esparció allí en todos sitios el desorden que reina en una cabeza confusa por el exceso de devoción \& las ideas novelescas ${ }^{61}$.

También Goethe, en su Viaje a Italia, da cuenta del cambio estético que se produce en la actuación que da el príncipe de Palagonia a la construcción anterior: El patio del palacio forma un redondel de casas de un piso, viviendas de la servidumbre y los trabajadores. El palacio, cuadrado, se levanta dominándolo todo.

Tal es la disposición tradicional en semejante especie de construcciones, como lo habrá sido probablemente hasta el tiempo en que el padre del Príncipe edificó el palacio, de un gusto, si no el mejor, a lo menos soportable. El actual poseedor, sin renunciar a aquellos rasgos generales, deja libre curso a su capricho y a su pasión a todo lo deforme y de mal gusto, y se le hace demasiado favor concediéndole sólo una chispa de imaginación ${ }^{62}$.

Los contrapuntos son como un juego de alegorías al estilo Barroco, y se van encontrando poco a poco en el paseo por la villa en ocasiones con pequeños gestos, en otros con grandes ostentaciones.

En primer lugar, el paseo de acceso a la villa y sus jardines quedó flanqueado por ese un gran número de esculturas monstruosas - de las que hoy no se conserva ninguna, porque el paseo fue demolido en aras del urbanismo-. El mismo tipo de esculturas flanquean el muro que rodea los jardines de la villa hoy todavía conservadas-. Este tipo de esculturas incluyen todo tipo de monstruos sacados a colación en los tratados clásicos escritos sobre la monstruosidad: sirenas, enanos, íncubos y súcubos, leones con cabezas humanas, dragones...

Así las describe el libro de Jean Houel: Todo lo que la tierra, el mar \& el aire pueden producir, hombres, cuadrúpedos, pájaros, peces o plantas que atraviesan los climas más opuestos, se encuentran allí juntos \& mezclados sin orden, sin elección \& sin gusto. El centauro, la esfinge, el dragón, la quimera, todas esas locas creaciones de pintores o poetas, se aproximan a más formas bizarras de las que se pudieron dar a las figuras \& y grupos que decoran tal avenida.

El Príncipe se recreó multiplicando las monstruosidades uniendo en una misma figura la forma humana con alas de pájaro, cola de pez, extremidades de cuadrúpedos, la trompa del elefante, los cuernos del jabalí, las garras del buitre, la cola del mono \& del reno; \&, por miedo a que ese conjunto no fuese suficientemente bizarro, les puso trajes peculiares, marcas, armaduras, instrumentos de guerra y musicales \& de caza ${ }^{63}$.

\footnotetext{
${ }^{61}$ BORCH. C. de (1782), vol. II, p. 102.

62 GOETHE (1891), Palermo, 8 abril 1787. Domingo de Pascua, pp. 271.

${ }^{63}$ HOUEL, J. (1781), vol. IV, p. 40.
} 
Y Saint-Non: 1. La multitud prodigiosa de Estatuas que rodean la casa (dice Bridone) parecen ser de lejos una pequeña armada, formada en orden de batalla para la defensa; pero conforme nos aproximamos, \& vemos la figura de cada una de ellas, creemos haber sido transportados a un País de ilusión \& encantamiento. Entre ese grupo inmenso no hay una sola pieza que represente un objeto existente en la naturaleza, \& no nos quedamos menos sorprendidos del desorden de la loca imaginación que inventa la forma, como de su fecundidad maravillosa [...] Ha puesto Cabezas de hombres sobre los cuerpos de diferentes animales, \& cabezas de todo tipo de animales sobre cuerpos humanos [...] Vemos una Cabeza de león sobre un cuello de ave, con un cuerpo de lagarto, las piernas de una cabra \& la cola de un zorro; sobre la espalda de ese monstruo ha puesto otro todavía más repugnante, que tiene cinco o seis cabezas \& un gran número de cuernos [...]

Las Estatuas que embellecen, o más bien que desfiguran la gran avenida, y rodean el patio del Palacio, ascienden ya a seiscientas ${ }^{64}$.

Henry Swinburne: A cada lado hay un muro parapeto repleto de las más horribles figuras que nunca habían sido creadas por Armida y todos los encantadores de Ariosto. Bustos de Policinellas y Arlequines con serpientes contorneándolos; cabezas de enanos con gigantescas pelucas y de asnos y caballos con pañuelos de encaje y collarines componen la gama baja de tal gallería, y en intervalos de diez yardas hay pilares recargados que soportan curiosos grupos de figuras; algunos son músicos, otros pigmeos, héroes de ópera, mujeres ancianas sonriendo, leones y otras bestias terroríficas comiendo ostras en mesas con servilletas bajo sus mentones; princesas con plumas, avestruces sobre aros y gatos con botas. En suma, más mezclas incontables de representaciones no naturales de criaturas de las que tenía paciencia para anotar, memorizar o recordar ${ }^{65}$.

Y Goethe: Queriendo presentar en su totalidad los elementos de la locura del Príncipe de Pallagonia, daremos la lista siguiente: Criaturas humanas: mendigos y mendigas, español, española, moros, turcos, jorobados, toda suerte de contrahechos, enanos, músicos, policinellas, soldados en traje antiguo, dioses, diosas, gentes vestidas a la antigua moda francesa, soldados con cartucheras y polainas. Mitología con adiciones burlescas: Aquiles y Chirón con Policinella. Animales o figuras incompletas: caballo con manos de hombre, cabezas de caballo sobre cuerpos de hombre, monos desfigurados, muchos dragones y serpientes, toda suerte de patas en figuras de todas clases, cabezas dobles y cabezas cambiadas. Jarrones: Toda suerte de monstruos y de ornamentos cuya parte inferior terminan vientres de jarrones o zócalos.

Imagínense semejantes figuras, ejecutadas a cientos, sin entendimiento ni sentido, reunidas sin plan ni elección; imagínense estos zócalos, estos pedestales y estos monstruos, en una fila que se pierde de vista, y se compartirá el sentimiento desagradable que se apodera de cada uno que recorre aquella senda de la locura ${ }^{66}$.

En segundo lugar, añade al jardín de la villa bancos y cornisas que quebraban la forma barroca. Si el Barroco ya había puesto el contrapunto al Renacimiento

\footnotetext{
${ }^{64}$ SAINT-NON, A. de (1786). Quatrième volume. Première partie.

${ }^{65}$ SWINBURNE, H. (1790), p. 325.

${ }^{66}$ GOETHE (1891), Palermo, 8 abril 1787. Domingo de Pascua, pp. 273.
} 
con las volutas, Ferdinando Francesco II añade un punto de contrapunto a ese Barroco. Goethe así lo describe: Pero lo absurdo de semejante mal gusto se muestra, en su más alto grado, en que las cornisas de las casas pequeñas se tuercen todas a un lado o a otro, de manera que el sentimiento del nivel y de la línea vertical, ley de la inteligencia humana y fundamento de toda simetría, se lastima y se nubla en nosotros. Los bordes de estos tejados guarnécenlos hidras, bustos pequeños, coros de monos músicos y otras insensateces semejantes. Los dragones alternan con los dioses, un Atlas, en vez de un mundo, sostiene un tonel de vino [...] Los pies de las sillas están serrados a distintas alturas, de manera que nadie puede sentarse en ellas, y el que enseña el palacio avisa que en los asientos de terciopelo de las que están sólidas, hay espinas escondidas ${ }^{67}$.

En tercer lugar, decora el salón de recepción previo a la entrada al Salón de los Espejos con frescos sobre los trabajos de Hércules. No olvidemos que fue él quien logró derrotar, capturar o matar a criaturas tan temibles como temidas. Quizás podríamos poner nombres Neoclásicos a tales criaturas que asolaban a Ferdinando Francesco II.

En cuarto lugar, recubre uno de los salones -hoy día llamado Salón de los Espejos- con espejos. Así, la estancia de recepción se convierte en un juego de imágenes en las que el propio visitante no es capaz de situar sus coordenadas en el espacio.

De esta forma lo describe el volumen de Patric Brydone: El interior del Castillo encantado responde exactamente al exterior: encontramos en todo lugar la locura \& la extravagancia del Maestro, \& y hacia cualquier lugar al que miremos, aparecen figuras originales. Algunas habitaciones son muy amplias $y$ magníficas: vemos allí techos con grandes bóvedas que, en lugar de yeso o estuco, están totalmente recubiertas de amplios espejos encajados entre sí exactamente: cada uno de esos espejos deja un pequeño ángulo con su vecino, produciendo el efecto de una multiplicidad, de modo que si tres o cuatro personas se pasean debajo, parece siempre que haya tres o cuatrocientos que caminan en la bóveda ${ }^{68}$.

En quinto lugar, decora los dormitorios con pinturas dedicadas a representaciones exóticas de supuestos viajes a Oriente: Los restos del gusto antiguo aparecen en una habitación equipada al estilo chino, con ollas chinas, pequeñas imágenes, piezas de diferentes vidrios colorados y ornamentos dorados, que juntos no brindan un mal efecto. El techo está recubierto de espejos reflectantes ${ }^{69}$.

$\mathrm{Y}$, por último, deja pequeñas inscripciones aisladas que sirven al visitante para comprender el sentido de su obra.

\footnotetext{
${ }^{67}$ GOETHE, ibid., pp. 274-275.

${ }^{68}$ BRYDONE, P. (1813), 1813, Palermo, 28 Junio.

${ }^{69}$ HILL, B. (1792), p. 89.
} 


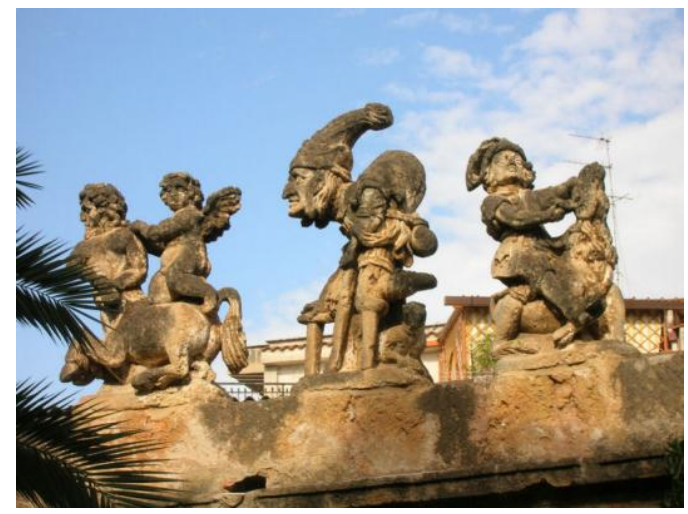

Villa Palagonia. Detalle de las esculturas añadidas por Ferdinando Francesco II Foto: Nieves Soriano Nieto

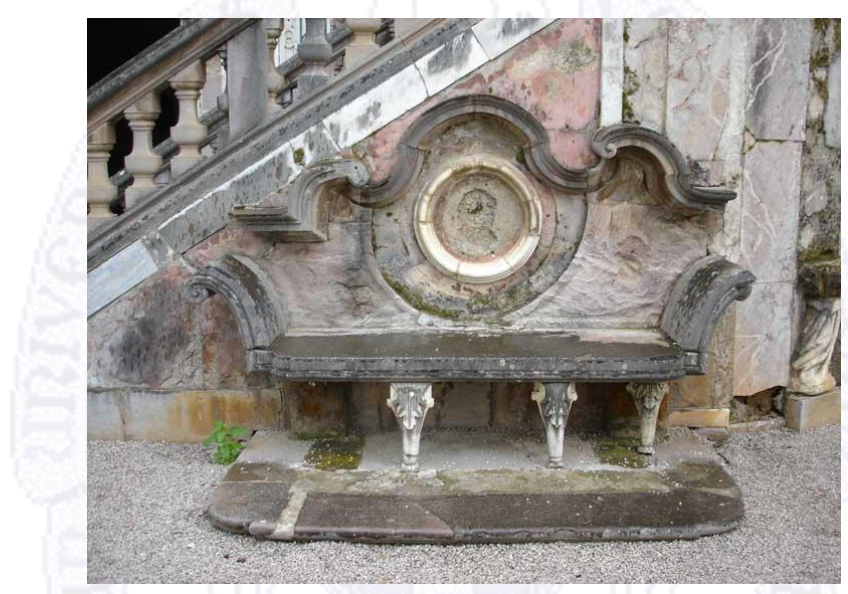

Villa Palagonia. Detalle del banco barroco de forma quebrada

Foto: Nieves Soriano Nieto

El príncipe Ferdinando Francesco II, ilustrado, había intuido y materializado el ímpetu de la línea de sombra del pensamiento dieciochesco. El sueño de la Razón produce monstruos. Así, el príncipe se permitió expresar una inquietud tal de una época de una forma brillante, dando punto final a la villa neoclásica con el toque de la monstruosidad, es decir, planteando su propia residencia como un lugar en el que convivían las que fueron las dos tendencias que han acompañado al ser humano desde el comienzo de la historia, y que especialmente tuvieron uno de los puntos álgidos en el siglo XVIII: Razón y Sinrazón no pueden ir diferenciadas. El espacio habitacional, que es el lugar privado en el que el ser humano desarrolla su intimidad, es una mezcla de ambas tendencias. Así, en él, el ser humano tiene una propia imagen de su interior (Bouchart y Beauthéac ${ }^{70}$ ).

${ }^{70}$ ¿Podría decirse que en el jardín el ser humano modela la naturaleza, que la reforma, que la deforma a su agrado? ¿No sería más justo decir que el jardín es la unión del ser humano y de la naturaleza para poner simultáneamente en un espacio delimitado y en un momento dado sus obras mutuas en valor?

BOUCHART, F.-X. y BEAUTHÉAC, N. Op. Cit., p. 5. 
Era una forma de expresar la Nada (Christine Buci-Glucksmann ${ }^{71}$ ), procedente de la estética barroca. Ese lugar en el que lo funcional se pierde para dejar paso a un baile de alegorías que transportan a un vacío catártico.

El ser humano se encuentra reflejado ante sí mismo. Y el reflejo le hace ser consciente de los límites de la grandeza humana, es decir, de la Razón. Él, ante su reflejo frente a los cristales del Salón de los Espejos, queda enfrentado ante sus mortal fragilidad, como dice una inscripción situada en el hall, Specchiati in quei cristalli, e nell'istessa magnificenza singolar, contempla di fralezza mortal l'imago espressa. [Reflejados en esos cristales, y en su misma peculiar magnificencia, contempla con mortal fragilidad la imagen explícita].

Bagheria se convierte así, gracias a la villa Palagonia, en uno de los lugares predilectos a la hora de realizar el viaje a Sicilia. Los viajeros desean tanto observar las esculturas monstruosas como ver los templos de Agrigento. Un atrevimiento de expresión tal resultaba a la mirada del viajero una experiencia que no podía osar perderse, en tanto que era una manifestación en un pequeño espacio del conjunto de la forma de pensar de una época. La villa Palagonia se convierte en un producto cultural síntoma de las inquietudes de un periodo histórico.

El viajero que pasaba por Sicilia podía evitar pasar por cualquier otro lugar, pero la villa Palagonia era de obligada visita. El que allí llegaba, dentro del marco teórico expuesto para la época, se enfrentaba directamente a la experiencia estética de lo sublime. Es decir, a la experiencia estética que aúna a un tiempo la atracción y la repulsión hacia el objeto. En el caso de la villa Palagonia, el baile de lo monstruoso hace que por un lado el viajero se enfrente hacia el miedo, y por otro lado, la curiosidad que le produce la maravilla de la monstruosidad, le atrae hacia ella.

Así, en la mayor parte de las ocasiones, los viajeros ilustrados que se acercaban a ella no podían evitar realizar comentarios sobre la fealdad del conjunto o la locura del príncipe Ferdinando Francesco II. Síntoma eran las palabras de los viajeros de la instaurada negación por parte de la ciencia, las categorías y el conocimiento de la época de la posibilidad de concebir la existencia de lo incomprensible, lo oscuro, lo inefable. Sin embargo, la llustración, ya dijimos, dedica un gran esfuerzo a tratar de mesurar lo monstruoso (teratología). El ímpetu de base es brindar luz a la oscuridad. El ámbito de lo monstruoso atrae de una forma dialéctica.

Patrick Brydone: El gobierno ha tenido serias consideraciones sobre demoler el regimiento de monstruos que ha colocado alrededor de esa casa; pero como él es humano e inofensivo, y tal hecho rompería su corazón, se han abstenido. Sin embargo, que sean observados por mujeres embarazadas se dice tiene como consecuencia circunstancias desafortunadas; algunos monstruos vivos se han creado en el vecindario. Las señoras se quejan de que ya no osan airearse en Bagheria; de que alguna forma espantosa siempre se aparecen en su imaginación durante mucho tiempo: sus maridos también, se dice, están poco satisfechos con la gran variedad de cuernos $^{72}$.

\footnotetext{
${ }^{71}$ BUCI-GLUCKSMANN, Ch. (1986).

${ }^{72}$ BRYODONE, P. (1813), p. 181.
} 
Jean Houel: Subimos a esa Casina, Palacio o Castillo, que se parece más a la estancia de un negromante que a la mansión de un príncipe, por una entrada doble que se une a la puerta del vestíbulo. Allí, en cualquier parte a la que miremos, vemos los disparates más monstruosos, chocantes y diversos. Observar tantos objetos incoherentes agota más de lo que se puede pensar y no brinda tanto placer como compensa con tanta pena ${ }^{73}$.

Henry Swinburne: Tal aventura de pandemonio me llevó a un patio circular delante de la casa, repleto de seres de piedra y mármol que no se encuentran en ningún libro de zoología [...] Tenía prisa por dejar ese mundo de monstruos, que casi me dejó mareado; el absurdo era tan burdo, la escena tan repugnantemente loca, que no pude forzar una sonrisa, sino reflejar mi asombro, el propietario debía haber sufrido para llegar tan lejos ${ }^{74}$.

Goethe: Pero si queremos enumerar una a una las aberraciones del príncipe de Palagonia, he aquí el elenco. Seres humanos: mendigos de los dos sexos, españoles, españolas, moros, turcos, jorobados, todo tipo de lisiados y enanos, músicos, pulguitas, soldados con trajes antiguos, dioses, diosas, figuras con viejos trajes franceses [...] Se piensa, además, que tales figura, profusas y en docenas con una inventiva privada de sentido y criterio, han sido reunidas indiscriminadamente y sin finalidad alguna; se imagina esta fila inmensa de zócalos, pedestales y deformidades, y podrá comprender cuán desagradable sensación siente cualquiera que forzado a pasar en medio de esos manotazos de locura ${ }^{75}$.

Tal es así que el silencio estético brota, síntoma ilustrado, ante la observación de lo monstruoso. Jean Houel sólo pudo dibujar de lejos la entrada hacia la verdad de una época.

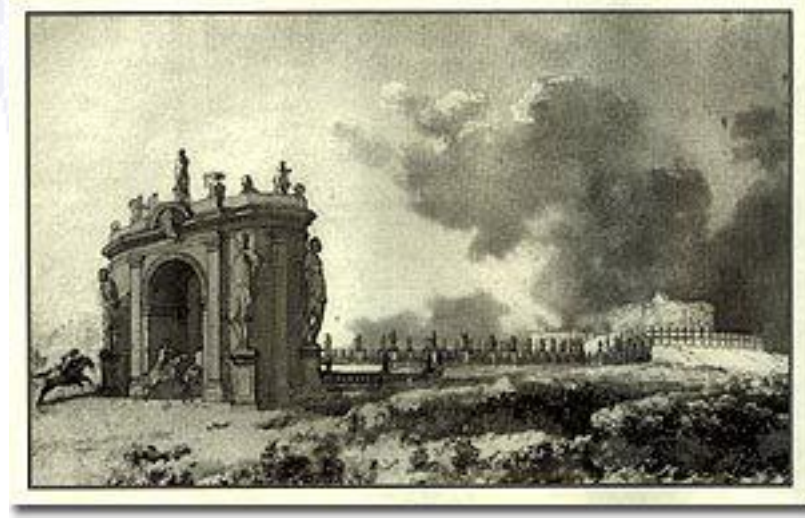

Jean Houel, Villa Palagonia.

Voyage pittoresque des îles de Sicile, de Lipari et de Malte

\footnotetext{
${ }^{73}$ HOUEL, (1781)., vol. I, Chapitre V, p. 42.

${ }^{74}$ SWINBURNE, H. (1790), vol. III, pp. 326-327.

${ }^{75}$ GOETHE (2009), Palermo, lunedì 9 aprile, 1787.
} 


\section{Bibliografía}

AAVV (1988), Bagheria. La città e le ville, Bagheria, Istituto de Cultura Siciliano,.

- (2004), El salvaje europeo. Catálogo de exposición conjunta en el CCCB y en la Fundación Bancaja de Valencia, Barcelona,.

(1988), Goethe in Italy, 1786-1986. Editado por Gerhart Hoffmeister, Ámsterdam, Rodopi.

._ (1997), Grand Tour. II fascino dell'Italia nel XVIII secolo, Milano, Skira.

(2009), Italy's Eighteenth Century. Gender and Culture in the Age of the Grand Tour, Stanford, Stanford University Press.

ARBILLAGA, I. (2005), Estética y teoría del libro de viaje: El viaje a Italia en España, Analecta Malacitana, vol. 55.

BASITRERI, R. (2008), Alchimia e architettura. Un percorso tra le ville settecentesche di Bagheria, Bagheria, Eugenio Maria Falcone Editore.

BASTRUSAITIS, J. (2006), II Medioevo fantastico. Antichità ed esotismo nell'arte gotica, Milano, Adelphi edizioni,.

BARTLETT, W. H. (1853), Pictures form Sicily, London, Arthur Hall, Virtue \& Co.

BATTISTI, E. (1962), L'Antirinascimento, Milano, Feltrinelli.

BENITO, A. (2008), "Monstruos y portentos: dos visiones antagónicas de las razas prodigiosas en la General Storia de Alfonso X" en Gemir, 12.

BERNHEIMER, T. (1979), Wild men in the Middle Ages, New York, Octagon books.

BERTRAND, G. (2008), Le Grand Tour revisité. Pour une archéologie du tourisme: le voyage des français en Italie, milieu XVIIle siècle-début XIXe siècle, Roma, École Française de Rome.

BLACK, J. (2003), Italy and the Grand Tour, Yale, Yale University Press.

BORCH, C. de (1782), Comte de, Lettres sur la Sicile et sur l'île de Malthe (pour servir de supplément au voyage en Sicile et à Malthe de Monsieur Brydonne), Turín, Frères Reycends.

BOUCET, P.-G. (1988), "Imagination, pregnant women, monsters in 18th century in England and France" en Rousseau and Porter. Sexual Underwolds of the Enlightenment, University of Northern Carolina Press.

BOUCHART, F.-X. y BEAUTHÉAC, N. (1982), Jardins fantastiues, Paris, Éditions du Monsieur.

BRYDONE, P. (1813), Tour through Sicily and Malta in a series of letters, NY., Evert Duyckinck. 
BUCI-GLUCKSMANN, Ch. (1986), La Folie du voir. De l'esthétique baroque, Paris, Galilée.

BURKE, P. (2002), Historia social del conocimiento. De Gutenberg a Diderot, Barcelona, Paidós.

._ (2005), ¿Qué es la historia cultural?. Barcelona, Paidós.

CANGUILHEM, G. (2004), Le normal et le pathologique, Paris, PUF.

CASTAGNA, U. (1998), L'Ultimo Principe. Storia di don Francesco Paolo Gravina, Napoli, Arte Tip. Ed.

CÉARD, J. (1996), La Nature et les prodiges. L'insolite au XVle siècle, Genève, Drox.

CECALA, R., Villa Palagonia. /I Barocco a Bagheria. Manuscrito conservado en la Biblioteca di Archeologia e Storia dell'arte di Roma.

CHECA FERNANDO Y MORÁN, J. M. (1989), El Barroco, Madrid, Istmo.

CHEVALLIER (1984), Iter Italicum. Les voyageurs français à la découverte de I'Italie ancienne, Genève, Slatkine.

COMETA, M. (1999), II romanzo dell'architettura. La Sicilia e il Grand Tour nell'età di Goethe, Bari, Laterza.

DASTON, L. y PARK, K. (2000), Le meraviglie del mondo. Mostri, prodigi e fatti strani dal Medioevo all'llluminismo, Urbino, Carocci.

DUMAS, A. (1842), Le Spéronare, Paris, Dumont.

ECO, U. (2007), Storia della Bruttezza, Torino, Bompiani.

ERNEST, M. (1880), Histoire des monstres depuis l'Antiquité à nos jours, Paris, C. Reinwald et Cie.

FOUCAULT, M. (2001), Los anormales, Madrid, Akal.

GOETHE (1891), Viaje a Italia, Traducción de Fanny G. Garrido de Rodríguez Mourelo, Madrid,.

. _ (2009), Viaggio in Italia, Milano, Mondadori.

.__ (1988), Philipp Hackert. La vita, Napoli, Edizione scientifiche italieane.

GUEVARA, FRAY A. de (1994), Relox de príncipes en Obras Completas de Fray Antonio de Guevara, Madrid, Fundación José Antonio Castro.

HACHET, P. (2002), Psychanalyse d'un choc esthétique. La villa Palagonia et ses visiteurs, Paris, L'Harmattan.

HAZARD, P. (1995), La crise de la conscience européenne (1680-1715), Paris, Fayard.

HAYDN, H. (1950), The Counter-Renaissance, NY, Charles Scribners.

HEGEL (2006), Fenomenología del espíritu, Madrid, Alianza.

HIBBERT, Ch. (1969), The Grand Tour, London, Putnam.

HILL, B. (1792), Observations and remarks in a journey through Sicily and Calabria, in the year 1791, London : J. Stockdale. 
HIPONA, A. de (2006), La ciudad de Dios, Madrid, Homo Legens,, XVI, 8-9.

HOCKE, G. R. (1989) H, Il mondo come labirinto. Maniera e mania nell'arte europea. Dal 1520 al 1650 e oggi, Roma, Edizioni Theoria.

HOUEL, J. (1781), Voyage pittoresque des îles de de Sicile, de Malte et de Lipari, Paris, Imprimerie de Monsieur.

(1990), Voyage en Sicile. 1776-1779. Catálogo de la exposición en el Museo del Louvre. 26 marzo-25 junio 1990. Paris, Herscher.

HUEL, M.-H. (1993), Monstrous Imagination, Cambridge, Massachusets, London, Harvard University Press.

KANT, I. (2004), ¿Qué es la ilustración? : y otros escritos de ética y filosofía de la historia, Madrid, Alianza.

KRÖNING, W. (1987), Vedute di luoghi classici della Sicilia. II viaggio di Philipp Hackert del 1777, Palermo, Selerio Editore.

LE GOFF, J. (1986), Lo maravilloso y lo cotidiano en el Occidente medieval, Barcelona, Gedisa.

(2007), "Au Moyen Âge, le merveilleux est bien réel"en Les collections de I'Histoire. Héros et merveilles du Moyen Âge, $\mathrm{n}$ 웅. Juillet-septembre.

LESSING (1990), Laoconte, Madrid, Tecnos.

LLINARES, J. B. (2008), "El mito del hombre salvaje en el Barroco: una lectura antropológica de La vida es sueño de Calderón" en AAVV, Congreso Internacional de Teatro Clásico Griego: Teatro y sociedad: Las relaciones de poder en época de crisis, Bari, Levanti Editori.

LUI, F. (2006), La Antichità tra scienza e invenzione. Studi su Winckelmann e Clérisseau, Bologna, Minerva Edizione.

MACCHIA, G. (1987), Le prince de Palagonia, Paris, Quai Voltaire.

MANDEVILLE, J. (1984), Libro de las maravillas del mundo, Madrid, Visor.

MARX, K. (2003), El Capital, Buenos Aires, Siglo Veintiuno editores.

MEAD, W. E. (2009), The Grand Tour in the Eighteenth Century, University of Michigan Library.

MOSCOSO, J. (2000), Materialismo y religión: ciencias de la vida en la Europa ilustrada, Barcelona, Ediciones Serbal.

(2001), "Los efectos de la imaginación: medicina, ciencia y sociedad en el siglo XVIII" en Asclepio, vol. LIII-1.

MÜNTER, F. (1790), Nachrichten über beide Sizilien.

MUSSET, P. de (1856), Voyage pittoresque en Italia, Paris, Morizot.

._ (1883), En voiturin. Voyage en Italie et en Sicile, Paris, Calman Lévy.

NIETO ALCALDE, V. y CHECA, F. (1989), El Renacimiento, Madrid, Istmo.

NIETZSCHE, F. (2005), El nacimiento de la tragedia, Madrid, Alianza.

PARJASSE, M. D.-D. (1835), L'Italie, la Sicile, les îles éoliennes, l'île d'Elbe, la Sardaigne, Malte, l'île de Calypso, etc., Paris, Audot. 
POLO, M. (1983), Viajes. Libro de las cosas maravillosas del Oriente, Madrid, Akal.

RINGMAR, E. (2006), "Audience for a Giraffe. European Expansionism and the Quest for the Exotic". Journal of World History, December.

ROUSSEAU, J.-J. (1961), Émile ou de l'éducation, Paris, Garnier.

RUSSEL, G. (1819), A tour through Sicily in the year 1815, London, Sherwood, Neely and Jones.

SAID, E. (2003), Orientalismo, Barcelona, Ediciones de Bolsillo.

SAINT-NON, A. de (1786), Voyage Pittoresque ou Description des Royaumes de Naples et de Sicile, Paris.

SALAMANCA BALLESTEROS, A. (2007), Monstruos, ostentos y hermafroditas, Granada, Ediciones de la Universidad de Granada.

SCADUTO, R. (2007), Villa Palagonia. Storia e Restauro, Bagheria, Eugenio Maria Falcone Editore.

SEGALEN, V. (1978), Essai sur l'exotisme, une esthétique du divers, Paris, Fata Morgana.

SENNETT, R. (1991), La conciencia del ojo. Barcelona, Versal.

(1997), Carne y piedra. El cuerpo y la ciudad en la civilización occidental, Madrid, Alianza.

SETA, C. de (1992), L'Italia del Grand Tour. Da Montaigne a Goethe, Napoli, Electa.

(1999), Vedutisti e viaggiatori in Italia tra Settecento e Ottocento, Torino, Bollati Boringhieri.

.__ (ed.) (2001), Grand Tour. Viaggi narrati e dipinti, Napoli, Electa.

SIMOND, L. (1828), Voyage en Italie et en Sicile, Paris, A. Sautelet et Compagnie.

SOMBART, W. (1998), El burgués: contribución a la historia espiritual del hombre económico moderno, Madrid, Alianza.

SORIANO NIETO, N. (2009), Viajeros románticos a Oriente. Delacroix, Flaubert y Nerval, Murcia, Editum.

SPINOZA, B. (2007), Ética demostrada según el orden geométrico. Madrid, Tecnos.

STAROBINSKI, J. (1988), 1789. Los emblemas de la Razón. Madrid, Taurus.

STRIEHL, G. (1998), Der Zeichner. Christoph Heinrich Kniep (1755-1825). Landschaftsauffassung und Antikenrezeption, Hildesheim, Georg Olms Verlag.

SWINBURNE, H. (1790), Travels in the Two Sicilies in the years 1777, 1778, 1779 and 1780, London, J. Nichols.

TEDESCO, N. (1986), L'Immago espressa. Villa Palagonia tra norma ed eccezione, Palermo, Ediprint.

THOMPSON, C. J. S. (2001), I veri mostri. Storia e tradizione, Milano, Mondadori. 
TODD, D. (1995), Imagining Monsters. Miscreations of the Self in EighteenthCentury England, Chicago, The University of Chicago Press.

TORQUEMADA, A. de (1943) [1570], Jardín de Flores Curiosas, Madrid, Soc. Biblio.. Español.

TORT, P. (1980), L'Ordre et les monstres. Le débat sur l'origine des déviations anatomiques au XVIIlème siècle, Paris, Le Sycomore.

TUZET, H. (1955), La Sicile au XVIIle siècle vue par les voyageurs étrangers, Strasbourg, Éditions P. H. Heitz.

WHITE, H. (1972), "The Forms of Wildness: Archeology of an Idea" en AAVV, The Wild Man Within. An Image in Western Thought from the Renaissance to Romanticism, Pittsburg, University of Pittsburg Press.

WILSON, D. (1993), Signs and Portents. Monstruos births from the Middle Ages to the Enlightenment, London, Routlet. 